\title{
Türkiye'deki Serbest Planlama Bürolarının Coğrafyası: Mekansal ve Sektörel Analiz
}

\section{Geography of Private Planning Offices in Turkey: Spatial and Sectoral Analysis}

\author{
D Binnur Öktem Ünsal, (ㄱ) Gizem Aksümer
}

Mimar Sinan Güzel Sanatlar Üniversitesi Mimarlık Fakültesi, Şehir ve Bölge Planlama Bölümü, İstanbul

\section{ÖZ}

Türkiye'de 2000'lerde hızlanan inşaat odaklı büyüme politikala- rı kentlerin hızlı yeniden yapılanmayı getirmiştir. Bu süreçte kentsel rantın yaratılması ve dağıtılmasında en önemli araçlardan birisi olan planlama kurumu, yasal ve yönetsel düzenlemeler ile kaotik ve dağınık bir hale gelmiştir. Planlama, siyaset ve piyasa ile ilişkileri bağlamında ülke gündeminde her zamankinden daha fazla yer alır iken, bu ekonomi politik altında planlama pratiğinin nasıl dönüştüğü ise çok az tartışıımıştır. Bu makale Türkiye'de mekânsal planların büyük bir çoğunluğunu yapan serbest planlama bürolarına, bu büroların coğrafyasına, karne yönetmeliğinin planlama bürolarının sektördeki faaliyetlerine etkilerine ve büroların yaptıkları işlere odaklanmaktadır. Bu kapsamda Şehir Plancıları Odasından temin edilen MDU verileri, anket ve derinlemesine görüşmelerden oluşan saha çalışması gerçekleştirilmiştir. Araştırmada planlama okulları ile birlikte büroların sayısının arttığı, büroların coğrafi olarak tüm Türkiye'ye yayıldığı tespit edilmiştir. Ankara'daki A grubu karneli bürolar piyasada hakimiyetlerini korur iken, ülkenin gelişmiş kentlerinde bölgesel hakimiyet kuran bürolar oluştuğu bulunmuştur. 2000 sonrasında sektör genişlemiş ve çeşitlenmiş, sektörün büyümesinde plan deği- şiklikleri en belirgin şehircilik hizmeti olarak ön plana çıkmıştır. Üst ölçekli planlar yada uzmanlık gerektiren planları daha çok A grubu planlama büroları yapar iken, plan değişiklikleri tüm karne grupları tarafından en yoğun yapılan iştir. Sektörde yeni iş alanları ortaya çıkmış olmasına rağmen farklı karne grupları arasındaki eşitsizlikler derinleşmiş, bürolar, özellikle genç bürolar, karne sınırlamaları, da-ralan piyasa ve siyaset-sermaye baskısı arasında sıkışmıştır.

Anahtar sözcükler: Planlama sektörü; planlama pratiği; serbest planlama büroları.

\section{ABSTRACT}

Construction-oriented growth policies accelerated the urbanization process in the 2000s in Turkey. A series of new legal and administrative arrangements destabilized Turkey's urban planning system, which was one of the most important tools in creating and distributing urban rents. For the first time, planning became a prominent political and market issue. However, the influence of the dominant economic policy on the spatial planning sector has seen little debate. This study focuses on private planning offices, their geographies, the impact of regulations on them and the variety of projects they serve. The data were obtained from analysis of all planning projects completed between 2003 and 2018 in Turkey by these private planning offices and approved by the relevant Chamber of City Planners, questionaries with planning offices in different cities of the country and structured interviews with planning office representatives in Istanbul and Ankara. The findings show that the number of private planning offices has increased because there are now more planning schools and that these planning offices have spread throughout Turkey. However, planning offices in Ankara still dominate the national planning sector country while planning offices in more developed cities have built their regional hegemony. The planning sector has grown after plan amendments became a prominent planning ser- vice. While upper scale spatial plans and sectoral plans are pre- pared by A-level private planning offices, plan amendments have become the main work of all planning offices. Private planning offices, especially newer ones, remain trapped between regula- tions and capital pressure.

Keywords: Planning sector; planning practice; private planning offices. 


\section{Giriş}

Türkiye'nin uzun zamandır izlediği inşaat odaklı büyüme stratejisi başta kentsel alanlar olmak üzere oldukça büyük bir coğrafyada toprak üzerinden rantın yaratılma ve dağıtılma konularında önemli tartışmalara yol açmıştır. Bu konu ülke tarihinde daha önceki yıllara nazaran çok daha sık ve yoğun biçimde hem siyasal hem de akademik tartışmalarda yer alır iken, kent planlama bu gelişmelerden en çok etkilenen meslek alanlarından biri haline gelmiştir. Şehir plancıları Türkiye'de mesleklerini kent planlarının hazırlanmasında ve onaylanmasında belirleyici olan kamu kurumlarında, kamu ya da özel şahıslar için bu planları ya da plan değişikliklerini hazırlayan serbest planlama bürolarında, akademik dünyada ve gayrimenkul sektöründe farklı pozisyonlarda icra etmektedirler. Şehir planlama formasyonuna sahip plancıların kendi meslek alanlarına hakimiyetleri ya da alana dair belirleyicilikleri ağırlıkı olarak 1980 sonrası gerçekleşmiş, meslek alanında aktif olan şehir plancılarııı sayısı ve yaptıkları iş çeşitliliği ise özellikle 2000 sonrası hızla artmıştır. Başta konut, ulaşım, enerji olmak üzere hem kentsel alanda hem de kırsal alanda büyük projelerin gerçekleştirildiği, arsa ve arazi piyasalarının kentsel dönüşüm projeleri ile yeniden düzenlendiği bu yıllarda sektör büyümüş ve genişlemiştir.

Türkiye'de planlamanın kurumsallaşma sürecinde ülkeye özgü birtakım koşullar ve gelişmeler özellikle yerel yönetimlerde planlama birimlerinin zayıf kalması ile sonuçlanmış, dolayısıyla planlama sektöründe serbest çalışan planlama bürolarının planların hazırlanması aşamasında ağırlığı başlangıçtan bugüne değin varlığııı sürdürerek devam etmiştir. Modern Türkiye tarihinde yapılan planların büyük bir çoğunluğu serbest çalışan plancılar tarafından hazırlanmıştır. 1933 Yapı ve Yollar kanununa kadar harita mühendisliği ve mimarlık formasyonuna sahip plancılar sektöre hâkim iken, 1930'lardan 1990'lara kadar mimar plancılar sektörde belirleyicidir. Şehir ve Bölge Planlama okullarının açılması, Şehir Planlama Odasının kuruluşu ve 2006'daki plan yapım yönetmeliğince plan yapma hakkının sadece okulların Şehir ve Bölge Planlama Bölümleri mezunlarına tanınması ile planlama formasyonuna sahip plancıların sektördeki belirleyiciliği artmıştır. Önceleri Ankara merkezli gelişen serbest planlama büroları zamanla İstanbul, İzmir, Eskişehir olmak üzere Anadolu'ya yayılmıştır.

Türkiye'de serbest planlama büroları 1980'den itibaren uygulanan neoliberal politikaların hakim olduğu ekonomi politik ortamda mesleklerini gerçekleştirmektedirler. Ülkede 2000 sonrasında güçlü bir ivme kazanan neoliberalleşme projesinin kentsel gelişme modeli emlak eksenli büyüme modelidir. Dönem boyunca kentsel ve hatta kırsal alanlarda yaratılan rantın, sermaye birikiminin kolay ve hızlı biçimi olarak neredeyse tüm toplumsal sınıflar ve gruplar tarafından kabul edilmesi şehir plancılarının meslek alanlarının dinamiklerini büyük ölçüde değiştirmiştir. Emlak eksenli projelerin artışı, kentsel rantları destekleyen finansal ve yasal düzenlemeler inşaat sektörünü dolayısıyla şehir planlama meslek alanının iş kapasitesini hem büyütmüş hem de çeşitlendirmiştir. Eş zamanlı olarak sektörde yaratılan iş kapasitesini dikkate almadan ve kamuda istihdam olanakları yaratılmadan çok sayıda açılan planlama okullarından mezun olan plancıların serbest planlama büroları kurmaya yönelmesi, sektörde işlerin bölüşümü konusunda ciddi bir rekabet ortamı yaratmıştır.

Bu makale Türkiye'deki kent planlama sisteminin az bilinen ancak etkinliği yüksek olan bir aktörüne, serbest çalsşan planlama bürolarının mekânsal dağılımı ve sektörel analizine odaklanmaktadır. Türkiye'de planlama sisteminin neoliberalleşme sürecinin ülkedeki planlama bürolarının coğrafi dağııımına ve yaptıkları planlama işine etkileri, büroların karne sahipliliği, kuruluş yılları, faaliyet gösterdikleri kentler ve faaliyet alanları üzerinden ortaya konulacaktır. Sektör içinde farklı zaman dilimlerinde kurulmuş olan planlama bürolarının sektörde hangi işlerde yoğunlaştıkları, sektörel ve mekânsal yoğunlaşmada etkili olan faktörler tartışılacaktır. Bu tartışmaya çerçeve oluşturmak amacıyla öncelikli olarak planlama meslek alanının pratiklerini belirleyen neoliberal kentleşme ve planlama tartışmalarına ilişkin literatüre yer verilecektir. İzleyen bölümde Türkiye'de mekânsal planlama sisteminin emlak eksenli büyüme modelinin etkinliğinin artmasına paralel olarak nasıl düzensizleştirildiği ve dağınıklılaştırıldığı ortaya konulacaktır. Daha sonra 2003 ile 2018 yılları arasında serbest çalışan planlama bürolarının ekonomik coğrafyasına odaklanılacaktır.

\section{Yöntem}

$\mathrm{Bu}$ araştırma temelde nicel ve nitel verilerin birlikte, birbirini tamamlamak amacıyla kullanıldığı bir yöntemle hareket etmektedir. Öncelikle çeşitli kaynaklardan toplanan nicel veriler kategorize ve analiz edilmiştir. Bu bağlamda araştırmanın ilk aşamasında Şehir Plancıları Odası'nın Genel Merkezinden 2018 yılı Odaya tescilli planlama bürolarının bilgileri ve yine 2003 ile 2018 yılları arasında Türkiye'de gerçekleştirilen tüm işlere ait Mesleki Denetim Uygulama (MDU) verileri alınmıştır. Tescilli şirketlere ait verilere dayanarak planlama bürolarının karne sahipliliğine göre coğrafi dağııımı tespit edilmiştir. Mesleki Denetim Uygulama verileri üzerinden ise Türkiye'deki planlama büroları tarafından yapılan işler karneye ve yapılan işe göre tasnif edilmiş, hangi büyüklükteki işleri hangi tür büroların yaptığı, iş yapılan illere göre uzmanlaşmaların olup olmadığı ve kamu ya da özel sektöre yapılan işler irdelenmiştir. Bu analizde özellikle de Ankara'nın önemli bir yere sahip olduğu anlaşıımıştır.

İkinci aşamada, İstanbul ve Ankara'da en çok iş yapan bürolarla yarı yapılandırılmış görüşmeler yapılmıştır. Yarı yapılandırılmış görüşmelerin temaları, işyeri öyküsü, büronun faaliyet alanları ve planlama sürecine ilişkin detaylardan oluşmuştur. Ayrıca beraber çalışılan kurumlar ve işyerinde çalışanlara dair bilgi- 
ler de bu görüşmelerde ortaya çıkarılmıştır. İstanbul'da 12, Ankara'da ise 5 planlama bürosu, Şehir Plancıları Odası Genel Başkanı ve Şehir Plancıları Odası İstanbul Şube Başkanı ile görüşmeler gerçekleştirilmiştir. Bu görüşmelerden elde edilen bilgiler ışığında araştırma ülkedeki tüm planlama bürolarını kapsayacak biçimde genişletilerek bir anket çalışması düzenlenmiştir. Anket çalışmasında, planlama bürolarının plan yapım deneyimleri irdelenmiştir. Bu anlamda kadrolarının nicelik ve nitelik özellikleri, büroların nerelerde bulundukları, hangi bölgelerde işler yaptıkları, hangi sektörlerde yoğunlaştıkları ve sorunlarına dair kapsamlı sorular sorulmuştur.

Ülkedeki toplam 727 büronun II 9'una ulaşılmıştır. Büroların mekânsal dağılımları, kuruluş yılları ve karne sahipliliklerine göre dengeli bir dağılım sağlanmaya çalışılmıştır. Anket yapılan büroların \%15'i Ankara, \%9'u İzmir ve \%8'i İstanbul da yer almaktadır. Bu illerin dışında 38 kentte yer alan planlama büroları ankete cevap vermişlerdir.

Sonuç olarak araştırmada pek çok yöntem ve tekniğin bir arada kullanıldığı, nicel verilerin yoğun olduğu ancak nitel görüşmelerle desteklenen bir metodoloji kullanılmış, bu metodoloji araştırmanın gereklerine göre şekillendirilmiştir.

\section{I. Teorik Çerçeve: Mekansal Planlamanın Neoliberalleşmesi}

Kırk yılı aşkın bir süredir dünya üzerinde gelişmiş ülkelerden gelişmekte olan ülkelere oldukça geniş bir coğrafyada plancılar neoliberal doktrinin öğretileri tarafından yönlendirilen piyasalarda mesleklerini icra etmektedirler. En genel tanımıyla kamusal hizmetlerin özelleştirilmesi, ekonominin deregüle edilmesi ve kamusal harcamalarda kesintiler ile refah devleti kurumlarının ve politikalarının yerine piyasa odaklı düzenlemelerin gerçekleştirilmesi olarak tanımlanabilecek olan neoliberalizm, 1970'lerden itibaren farklı coğrafyalardaki birçok kentin sosyo mekânsal dönüşümünde etkili olmuştur (Waterhood, Othengrafen ve Sykes, 2013; Brenner ve Theodore, 2002). Dünya ekonomisinin yeniden yapılandığı bu süreçte sanayi büyük oranlarda gelişmiş ülkelerden gelişmekte olan ülkelere desantralize olmuş, uluslararası sermaye, mal ve insan hareketleri artmış, yeni küresel ekonomi belli kentler ve bölgeler üzerinden organize edilir ve yönetilirken, kentlerin ve ülkelerin ekonomik krizden çıkabilmesi ve büyüyebilmesinin koşulunun küresel ekonomiye eklemlenme olduğu yaygın kabul görmüştür. Kentlerde, ekonomiyi canlandırmak, sanayisizleşmenin yarattığı başta yapısal işsizlik olmak üzere diğer sosyal ve mekânsal sorunları çözmek üzere üst düzey hizmet sektörlerinin gelişimi teşvik edilmiş, uluslararası akışkanlığı artan sermayeyi çekmek için büyük kentsel projeler ve altyapı yatırımları geliştirilmiştir. Lüks alışveriş ve konut projeleri, uluslararası iş merkezleri, büyük iletişim ve altyapı yatırımları, uluslararası organizasyonlara ev sahipliliği yapmak merkezi ve yerel yönetimlerin önceliği olmuştur. Sermayenin artan hareketliliği sonucu özellikle de büyük ölçekli emlak geliştirme projeleri formunda kentlere büyük ölçekli sermaye yatırımları gerçekleşmiştir (Taşan Kok, 20I2). Girişimci kent yönetimleri tarafından kentler küresel ekonominin ihtiyaçları/talepleri üzerinden yeniden yapılandırılırken; kentsel mekan en karlı yatırım alanlarından biri haline gelmiştir. Kentsel mekanın metalaşması yolu ile sermaye birikimi, tüm dünyada kapitalizmin krizini ötelemek için mekânsal bir çözüm aracı olmuştur (Harvey, 200I). Kentsel projeler çöküntü alanları, eski sanayi, depolama, liman alanları, yıpranmış sosyal konut alanları gibi emlak değeri henüz maksimize edilmemiş kent parçalarını hedeflemiştir. Yeni küresel ekonominin sadece gelişmiş ülke kentleri için değil eğer doğru politikalar uygulanırsa gelişmekte olan ülke kentleri için de ekonomik gelişmesi için firsatlar sunduğu söylemi gelişmekte olan ülke kentlerinde de etkili olmuş, yerel yönetimler hızla büyük kentsel projeler gerçekleştirmişlerdir. Neoliberal kentleşme dinamikleri kentsel gelişmenin büyük oranda enformal ilişkiler içinde gerçekleştiği bu kentlerde hızla enformel alanları çeşitli yasal düzenlemelerle formel piyasalara eklemleyerek emlak sektöründe canlanmaya yol açmıştır. Dönem boyunca yapılı çevre üretimi dünya ölçeğindeki finans kuruluşları için kârı bir yatırım alanı olur iken, özellikle gayrimenkul sektörü kullanım ihtiyacından bağımsızlaşarak spekülatif bir yatırım aracı haline gelme eğilimi göstermiştir (Yeşilbağ, 2016). Küresel ekonomiye eklemlenmek ve uluslararası sermayeyi çekme odaklı politikalar gayrimenkul sektöründeki dinamikler ile birlikte, hem gelişmiş Batı ülkelerinde hem de gelişmekte olan ülkelerde kentsel rantları sermaye birikim stratejilerinin en kârlı alanlarından biri yapmıştır. Dolayısıyla inşaat ve gayrimenkul sektörü özellikle 2008-2009 krizine kadar hızlı bir büyüme göstermiş, sonrasında ise farklı coğrafyalarda farklı büyüme trendleri ile önemini korumaya devam etmiştir.

Ekonomik büyümeyi finanse etmek için devletin kentsel düzenlemeye ve kentsel toprakların metalaşmasına yönelik artan ilgisi, neoliberalizmin devletin küçülmesine olan vurgusunun aksine neoliberal kentleşme projelerinde devletin aktif olarak rol alması ile sonuçlanmıştır. Kamu ile birlikte ekonomik, politik ve kültürel elit gruplar neoliberal projenin uygulanmasında etkili olmuş, çoğu zaman kamu özel ortaklıkları ile büyük kentsel projeler gerçekleştirilmiştir. Kamunun aktif rol aldığı neoliberalleşme projelerinin inşasında devletin elindeki en önemli düzenleme araçlarından birisi ise planlama olmuştur. Sager (20II) neoliberalizm kavramının plancıların çalıştığı koşulları yaratan politik eğilimleri ve bürokratik dönüşümleri tanımladığını, bu nedenle de planlamadaki dönüşümleri anlamak için yararlı olduğunu ileri sürmektedir.

Neoliberalizm planlamanın önceliklerini değiştirmiştir. Modernist planlamanın önceliği İki Dünya Savaşı arasında, sınıfların taleplerine eşit yaklaşan, emeğin yeniden üretimi için gerekli kamusal hizmetlerin mekanda eşitlikçi dağılımını hedefleyen Keynesyen politikalar tarafından belirlenirken, neoliberal politikalarla birlikte sermayenin taleplerini önceleyen bir yaklaşıma evrilmiştir (Taşan-Kok, 2016). Klasik modernist planlama 
yaklaşımı özellikle $1980^{\prime} l e r d e$, kamunun rolünün çok güçlü olduğu, bütüncül, katı ve uzun vadeli yapısının piyasaların etkinliğini ve verimliliğini olumsuz yönde etkilediği, maliyetleri artırdığı ve projelerin uzamasına neden olduğu gerekçeleri ile eleştirilmiştir (Baker vd., 2006). Ancak Sager'in (20II) de işaret ettiği üzere bu eleştirilere rağmen kamusal planlama, gayrimenkullerin değerini diğer arazi kullanım kararlarının yaratıı̆ı negatif dışsallıklardan koruduğu için geçerliliğini devam ettirmiştir. Ancak planlamanın öncelikleri değişmiştir. Neoliberal politikaların yaygınlık kazanması ile planlamanın var olma nedeni olan piyasanın başarısızlıklarını engelleme ve düzenleme özellikleri terk edilmiş, planlama kentsel gelişmeyi ya da büyümeyi öncelikli hedef olarak tanımlayan mekânsal düzenlemeleri destekler olmuştur (Gleeson ve Low, 2000). Allmendinger ve Haughton'a (2013) göre planlamanın piyasaları destekleyen önemli bir rolü vardır. Ancak sermayenin yatırımlarının kentler üzerindeki talep ve beklentileri planlamanın sürekli değişmesine yol açmaktadır (Hall ve Hubbard, 1996). Planlama sistemi düzenli olarak ancak verimsiz bir biçimde piyasaları desteklemek için en kusursuz ölçeği ve kurumsal sabitleri aramakta, bu nedenle de farklı dönemlerde planlama sektöründe farklı ölçekler tercih edilmektedir (Allmendinger ve Haughton, 20I3). Taşan Kok (20I2) ise planlamanın neoliberalleşmesinin sadece planlamanın özel sektör aktörlerinin talepleri yada ihtiyaçlarına hizmet etmesi değil, aynı zamanda neoliberal politikaların yarattığı kentsel çelişkilere de cevap vermek olduğunu ileri sürmüştür. Bu çelişkilerin başında piyasa merkezli dinamiklere temellenen neoliberal kentsel gelişme sisteminin ancak arazi kullanım kararları planlama kurumları tarafından düzenlenirse işleyebileceği olmasıdır (Taşan Kok, 20I2). Birçok ülkede farklı biçimlerde de olsa planlama, neoliberal kentleşme sürecinin yarattığı taleplere yada çelişkilere cevap verirken, uzun vadeli, kapsamlı ve bütüncül planlamanın yerini 1980'lerden itibaren esnek, parçacıl, talep eksenli, kısa ve orta vadeli planlama almış, planlamanın odağı önce kentsel projelere, 1990'lardan itibaren ise eylem planları odaklı stratejik mekânsal planlamaya kaymıştır (Taşan Kok, 2012; Hall ve Hubbard, 1996).

Diğer taraftan merkezileşme derecesi ülkeden ülkeye farklııık gösteren, merkezi ve bürokratik bir yapıya sahip olan mekansal planlamada neoliberalleşme ile birlikte başta gelişmiş Batı ülkelerinde olmak üzere birçok ülkede özel sektörde çalışan plancıların etkinlikleri artmaya başlamışır (Zanotta, 2019). Yerel yönetimlerin bütçelerindeki daralma, kamuda yetersiz sayıda plancı olması, yerel yönetimler üzerindeki zaman baskısı, kamuda sınırlı uzmanlık kapasitesi ve planlama sürecinin daha sofistike hale gelmesi özel sektörde çalışan plancıların sektörde etkinliğinin artmasında öne çıkan nedenlerdir (McCann, 200I; Grijzen, 20I0, Parker vd.,2014; Momani ve Khirfan, 20I3). Türkiye'de ülkeye özgü nedenlerden dolayı daha ilk baştan beri serbest planlama bürolarının mekânsal planların elde edilmesindeki rolü büyüktür. Ancak 1980'de uygulanmaya başlanan 2000 sonrasında ise güçlenen neoliberal politikalar ve uygulamalarla birlikte emlak eksenli büyüme modeli plancı- ların plan yaptıkları ortamın dinamiklerini büyük ölçüde değiştirmiştir. Emlak eksenli büyüme modeli ile projeler ve planlar sektörel ve ölçek olarak çeşitlenmiş, planlama piyasası inşaat sektöründeki büyümeye paralel olarak genişlemiş̧ir. İzleyen bölümlerde önce Türkiye planlama sisteminin neoliberalleşme dinamiklerine, daha sonra ise 2000 sonrası emlak eksenli büyüme modelinin yarattığı piyasa dinamikleri içinde büyüyen planlama sektöründeki serbest planlama bürolarının coğrafyasına ve yaptıkları işlerin dönüşümüne odaklanılacaktır.

\section{Türkiye Planlama Sisteminin Düzensizleştirilmesi}

Türkiye Cumhuriyeti'nin kuruluşunu izleyen yıllardan itibaren modern bir ulus devletin inşası için planlama sisteminin kurumsallaşmasına yönelik önemli adımlar atılmış, ancak ülkenin planlama sisteminin kurumsallaşması büyük oranda II. Dünya Savaşı sonrasında gerçekleşmiştir. Çok partili siyasal rejime geçiş, tarımda makineleşme ve 1953 'ten itibaren izlenen ithal ikameci sanayileşme politikaları sonucu hızlı bir kentleşme ortaya çıkmış, başta İstanbul, Ankara ve İzmir olmak üzere büyük kentlerin hemen çeperinde enformel ilişkiler içinde sanayi alanları ve gecekondu mahalleleri, kentlerin planlı alanlarında yapsatçılık ilişkileri içinde yoğunluğu artarak dönüşen alanlar ortaya çıkmıştır. 1950'lerin başlarından itibaren bölgeler arası dengenin sağlanması, kentleşmenin yönetilebilmesi için bölge ölçeğinde planlamayı da içeren yeni bir kent planlama sistemi yaklaşımı ve şehir ve bölge plancısı yetiştirme gereklerini vurgulayan tartışmalar yoğunlaşır. 1956 yılında ilk kapsamlı İmar Kanunu çıkarılmıs, 1958'de kentlerin planlarını hazırlamak ve/ veya hazırlatmak ve onama yetkisi ile donatılmış İmar ve İskan Bakanlığı, 1960'ta ise kalkınma planları hazırlamakla görevli Devlet Planlama Teşkilatı kurulmuştur. Bakanlık bünyesinde Bölge Planlama Dairesi kurularak birçok bölge planı yapılmıştır. 196I'de ODTÜ'de kent planlama eğitimi verilmeye başlanması, 1969'da Şehir Plancıları Odası'nın (ŞPO) kurulması ise meslek alanının kurumsallaşmasında önemli adımlardır. 1957 yılında yürürlüğe giren ve 1972 yılında $I 605$ sayılı yasa ile güçlendirilen 6785 sayılı İmar Kanunu ile planlar arasında kademelenmenin tanımı yapılarak Nazım ve İmar Planı kavramları geliştirilmiş, metropoliten alanların planlaması için Bakanlığa bağı Nazım Plan Büroları kurulmuştur. Büyük kentlerin dışındaki diğer kentlerin planları ise İller Bankası tarafından yarışma, emaneten ama en sık da ihale yolu ile elde edilmektedir. 1933 ile 1980 arasında Türkiye'deki tüm planların \%96, 6l'i Iller Bankası tarafından yapılmıs, bu planların çok büyük bir kısmı ise serbest planlama büroları tarafından gerçekleştirilmiştir (Yanaşık, 2017). Ancak 1960 sonrası gelişen teknokrat modernizm özellikle büyük kentlerdeki kentleşme süreçlerini yönetmede yetersiz kalmıştır.

Ülkenin 1960'larda ve 1970'lerde art arda yaşadığı siyasi ve ekonomik krizler, bu krizleri aşmak üzere 1980 'de gündeme getirilen neoliberal reçeteler toplumsal alanın birçok dina- 
miğiyle birlikte mekânsal planlamayı da yeniden biçimlendirmiştir. İthal ikameci sanayileşme politikaları terk edilerek, ihracatı teşvik eden dışa açık neoliberal bir ekonomi modeli benimsenmiş, spekülatif kent ve turizm rantları, finans ithalat ve ihracat ile birlikte en önemli rant arama ve rant yaratma alanları olmuştur (Boratav vd., 1996). Neoliberal politikaların 1980'lerdeki temsilcisi ANAP hükümetlerinin kentleşme politikaları uluslararası sermayeyi İstanbul'a çekerek kenti dünya kenti yapmak, ülkenin güney ve Batı sahillerini turizme açmak, daha sonra Anadolu kaplanları ismi verilecek belli sanayi kentlerinin ihracat potansiyelini teşvik ederek dünya ekonomisine kentler üzerinden eklemlenmektir. Devlet, konut piyasasını düzenlemek üzere kurduğu Toplu Konut İdaresi (TOKI) üzerinden alt orta gelir grubuna ait kooperatiflerin gelişimini desteklemiş, gecekondu alanlarına yönelik aflarla 1960'larda başlayan metalaşma sürecini hızlandırmış, ülkenin Batı ve Güney kıyılarındaki turizm beldelerini ikinci konut ve turistik tesisler ile yapılaşmaya açmıştır. Neoliberalizmin bürokratik mekanizmalar nedeni ile planlamanın ağır işlemesi ve kentteki gelişmelerin arkasında kalması gibi eleştirileri Türkiye'de de karşılığını bulmuş, İmar ve İskan Bakanlığı ve Nazım Plan Büroları kapatılmış, 1985'de çıkarılan 3194 sayılı imar kanunu ile planlamada yerelleşme ve demokratikleşme söylemleri altında plan yapma, onama ve uygulama yetkisi yerel yönetimlere verilmiştir. Planlar üzerindeki Bakanlığın denetim mekanizması kaldırılmış, ancak yerel yönetimlerin plan yapma, onama, uygulama ve denetleme yetkilerini doğru, yerinde ve bilimsel dayanakla kullanımını sağlayacak finans, kadro ve teknik alt yapı donanımları eksik kalmıştır. Kent bütününe yönelik planlar yerine parçacıl planlarla 1980'lerde inşaat sektöründe hızlı bir büyüme yaşanmış, daha önce özel mülk sahibi, küçük girişimci, yapsatçı, gecekondu sahiplerine bırakılan kentsel rantlara, büyük sermaye ve arsa mafyası da talip olmuştur (Kubin, 1994). 1980'li yılların sonlarından başlayıp 1990'lı yıllar boyunca özellikle de merkezi yönetim ile yerel yönetimlerin farklı siyasi partiler tarafından yönetildiği dönemlerde kentsel rantlara el koyma ve dağıtma adına mücadeleler yaşanmış, bu mücadelelerin sonunda bir dizi yasal ve yönetsel düzenleme yapılarak plan yapma ve onama yetkisine sahip kamu kurum ve kuruluşlarının sayısı hızla artırılmıştır.

Planlamanın kuralsızlaştırıldığı ve denetimsizleştirildiği bu dönemde finansal ve teknik kapasiteleri düşük olan yerel yönetimlerin nazım ve uygulama imar planlarını hala IIller Bankası yapmakta ya da yaptırmaktadır, ama artık planlama işinin kendisi de ıslah imar planları, ilave konut alanları, belde planları, turistik tesisler için vaziyet planları gibi kent parçalarına yönelik planlar ile çeşitlenmeye başlamıştır. Yerel yönetimler kentsel rantlara yönelik yoğun olarak bu tür parçacıl plan talepleri ile karşılaşmış, çoğu zaman bu süreci yönlendirmek ve kentsel rantlardan nemalanmak yada siyasi kayglarla mevcut durumu meşrulaştırmak adına plan bütünlüğünü bozan kararlar almışlardır (Yoloğlu, 20।4). Kamu bütüncül planlama fikrinden uzaklaşırken, 1980 ile 1990 arasında beş üniversitede daha planlama eğitimi verilmeye başlanmış, böylece planlama eğitimi veren okul sayısı altıya çıkmıştır.

200 I ekonomik krizinin ardından yönetime gelen ve 2003'ten itibaren iktidarda olan mevcut hükümet, neoliberal dönüşümü hızlandırmış, merkezinde inşaat sektörünün olduğu dış kaynağa bağımlı ve tüketime dayalı bir ekonomi politikası izlemiştir. 2002-2010 yılları arasında inşaat sektöründe büyüme siyasetin tercihleri ve konuta yönelik güçlü talep ile ilişkili iken, 2010 sonrası iktidar açısından yegane iktisat politikası haline gelmiş, toplumsal ve siyasal alanlardaki karar ve tercihler ise inşaat ekonomisinin gereksinimleri doğrultusunda alınmıştır (Balaban, 2019). İnşaat sektörünün yükselmesi ile tarihi kent merkezleri, gecekondu alanları, orta sınıf konut alanları, eski sanayi, liman alanları kentsel dönüşüm projeleri ile dönüştürülmüş; kentlerin çevrelerinde saçaklanmış yeni konut alanları ortaya çıkmış; kırsal alanlarda, kıyılarda, ormanlarda turizm, enerji ve maden yatırımları yaygınlaşmış ve büyük ulaşım projeleri gerçekleştirilmiştir (Şahin, 2019). Ekonomik büyümeyi kentsel mekanın üretimi üzerinden sağlamak isteyen merkezi yönetim, kentlerde oluşan değer artışlarından yararlanmak amacıyla bu artışın yeniden dağılımını bizzat kendisi sağlamak istemiş ve TOKI gibi kurumlarla doğrudan bir piyasa aktörü niteliği kazanmıştır (Özler, 2019). Başta kamu kurum ve kuruluşları olmak üzere toplumun genelinde hızlı kentleşmenin getirdiği kentsel rantlardan daha yüksek pay alma çabası imar planı değişikliklerine olan talebi artırmıştır (Yoloğlu, 20।4; Kahraman, 20I0). İmar yasası ile parçacı planlamanın önünün "sınırsız" biçimde açılması, planlamada ve uygulamada denetim mekanizmalarının kurulmaması gibi nedenlerle başta ilave ve mevzii planlar olmak üzere sektörel planlar, merkezi konut yatırımları ve af yasaları ile çok geniş alanlar planlanmıştır (Kentleşme Şurası, 2009). Birçok kentte imar planlarıyla kentsel gelişme alanı olarak planlanmış alanlar, kentin gelecek yirmi yıllık nüfus kestirimlerinin iki katı büyüklükte nüfusun yaşayabileceği kadar büyük alanlara ulaşmıştır (Kentleşme Şurası, 2009).

AKP iktidarının Avrupa Birliği katılım ve müzakere sürecine bağlılı̆ının devam ettiği ilk yıllarında geniş kesimlerin katılımı ile planlamaya ilişkin politikaları ve stratejileri içeren Bütünleşik Kentsel Gelişme Stratejisi ve Eylem Planı-Kentges (20102023) 2010 tarihinde onanarak yürürlüğe girmiştir. Ülkenin mekânsal planlamaya ilişkin politika çerçevesini oluşturan belge, planlamada yönlendirici olamamış, kentleşme ve planlama alanı bütünleşik bir stratejiden yoksun bırakılarak, 1980’lerde başlayan sektörel temelli, çok otoriteli yapı yeni yasal ve yönetsel düzenlemeler ile daha da parçalı ve dağınık hale getirilmiştir (Duyguluer, 2006). Planlama ile ilgili kurumlarda oluşan birikim ve deneyim yok edilmiş, İller Bankası, Bayındırık ve İskan Bakanlığı gibi kurumlar işlevsizleştirilmiş, planlamadaki yetki dağılımı sorununu çözmek adına 20l I yılında Çevre ve Şehircilik Bakanlığı kurulmuştur. Bu bakanlığın ise yasal ve yönetsel karmaşaya yanıt üretmediği, geniş yetkilerle donatıldı̆̆ı ve yer yer de yerel yönetimlerin görevlerini üzerine alarak 


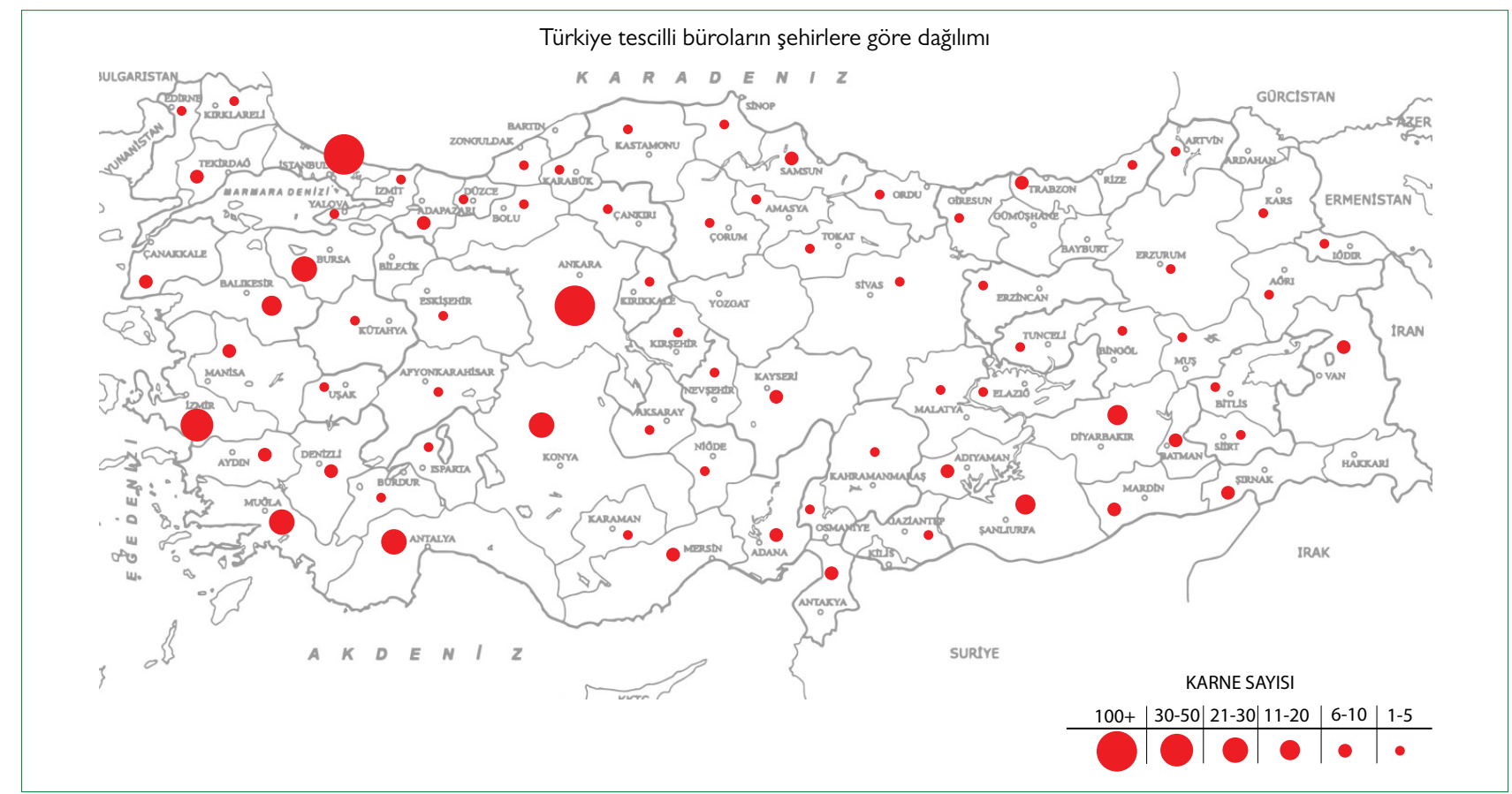

Şekil I. Türkiye'de ŞPO'ya tescilli planlama bürolarının şehirlere göre dağıımı (ŞPO-20।8).

ŞPO: Şehir Plancıları Odası.

ilerleyen süper bir Bakanlığa dönüştüğü eleştirisi pek çok çevrece yapılmaktadır (Mimarlar Odası, 20I I; Ersoy, 20l I). 20I I yılında dağıtılmış yetkiler nedeniyle, 61 çeşit plan türü, 19 kamu kurum ve kuruluşunun yetkili olduğu bir planlama ortamı vardır (Ersoy, 20I I: 4). Planlamada yetkili kamu kurum ve kuruluşlarının sayıca çokluğu, bu kurum ve kuruluşlar arasındaki yetki karmaşası, farklı plan türleri ve ölçeklerinin yarattığı kaotik ortam 20 I l yılı sonrasında da artarak Türkiye planlama sisteminin en önemli sorunlarından biri olarak varlığını korumuştur (Şahin, 2017: Sarı, Yener ve İnan, 2018).' Bu dönemde planlama kurumu bir taraftan neoliberalleşmenin kentsel alanda yarattığı dönüşümlerin baskısıyla düzensizleştirilirken, diğer taraftan neoliberalizmin ülke eğitim sisteminin birçok alanında olduğu gibi planlama eğitiminde yarattığı sorunlar ile karşı karşıya kalmıştır.

Türkiye'de sektörün reel ihtiyaçlarını dikkate almadan birçok planlama bölümü açılmış, 2000'li yıllarla birlikte şehir plancılarının sayısı hızla artmıştır. Kamuda iş imkanlarının kısıtlı olması yeni mezunları planlama bürosu kurmaya itmiştir. İnşaat odaklı büyüme stratejisi, siyaset, bürokrasi ve sermayenin rant odaklı baskıları, planlama sisteminin yasal ve yönetsel düzenlemeler ile oluşturulan çok aktörlü ve çok sektörlü yapısı, plansız artan plancı sayısı planlama bürolarının coğrafyasını, yaptıkları işin çeşitliliğini, planlama bürolarının kamu ve özel sektör ile kurdukları ilişkileri değiştirmiştir. Aşağıdaki bölümler planlama bürolarına dair mekânsal ve sektörel bir analiz sunmaktadır.

\section{Serbest Planlama Bürolarının Türkiye Coğrafyasına Yayılması}

Türkiye'de 2000'li yıllarla birlikte şehir plancılarının sayısı hızla artmış, kent planlama piyasasındaki hakimiyet şehir plancılarına geçmiştir. 2000'e kadar toplam II okulda şehir ve bölge planlama okulu var iken, 2000 ile 2019 yılı arasında 22 yeni şehir ve bölge planlama bölümü açılmıştır (ŞPO, 2019). ŞPO'nun kayıtlarına göre 2005 yılında şehir ve bölge planlama bölümlerinden mezun plancı sayısı yaklaşık 5000 iken, 2019 yılı itibari ile odaya kayıtlı plancı sayısı 9800'dür. ${ }^{2}$ Ancak Yoloğlu'na (2008) göre Odaya kaydolma oranı son yıllarda düşmektedir. $\mathrm{Bu}$ da mezun şehir plancısı sayısının daha yüksek olduğunu göstermektedir. Türkiye'deki belediyelerde ise 2016 yılında toplam 1528 plancı çalışmaktadır (Kentges Gelişme Raporu, 20I6). ${ }^{3}$ ŞPO'ya göre son yıllarda hızla sayıları artan planlama okullarından mezun plancılara yönelik kamuda yeterli istihdam olanaklarının gelişmemesi ve bütüncül planlama yaklaşımından uzaklaşıp, parçacıl-projeci bir yaklaşımla, parsel bazında plan değişiklikleri yolu ile planlama hizmetlerinin yaygınlaşması

\footnotetext{
I Sarı, Yener ve İnan tarafından hazırlanan Mekânsal Plan Yapma Yetkisi Olan Kuruluşlara ilişkin Tablo 2 bu kurum ve kuruluşları ve plan türlerini ayrıntılandırmaktadır (Sarı, Yener ve İnan, 2018: 27)

2 2019-2020 yılı için ise toplam kontenjan 2105’e çıkarılmıştır (ŞPO, 2019).

3 Bu rakama belediyelerin iştiraklerinde çalıştırılan şehir plancıları dahil değildir. Ancak ülkenin en kalabalık nüfusa sahip ve en fazla sayıda plancı istihdamının olduğu il olarak İstanbul özelindeki veriler incelendiğinde Büyükşehir Belediyesi, bağlı iştirakleri, ilçe belediyeleri, Valilik, Alan Başkanlığı da dahil olmak üzere toplam Şehir Plancısı istihdamının 393 olduğu görülmüştür. Bu rakam metinde belirtilen belediyelerdeki toplam plancı sayısını çok fazla değiştirmemektedir.
} 
Tablo I. Aktif büroların kuruluş yıllarına göre dağılımı (20| I-20|9)

\begin{tabular}{lccccccccc}
\hline Yıllar & 2011 & 2012 & 2013 & 2014 & 2015 & 2016 & 2017 & 2018 & 2019 \\
\hline Büro sayısı & 661 & 599 & 717 & 571 & 607 & 658 & 699 & 727 & 742 \\
\hline
\end{tabular}

Kaynak: Şehir Plancıları Odası.

Tablo 2. Yıllara göre yeni kurulan büro sayıları

\begin{tabular}{|c|c|c|c|c|c|}
\hline \multicolumn{2}{|l|}{2000 öncesi } & \multicolumn{2}{|c|}{ 2000-2009 arası } & \multicolumn{2}{|c|}{2009 sonrası } \\
\hline ì & Sayı & il & Sayı & il & Sayı \\
\hline Ankara & 5 & Ankara & 5 & Ankara & 6 \\
\hline İstanbul & 4 & İstanbul & 3 & İstanbul & 2 \\
\hline İzmir & $\mathbf{I}$ & İzmir & 5 & İzmir & 4 \\
\hline Aydın & 4 & Mersin & 2 & Adıyaman & 2 \\
\hline Tekirdağ, Samsun ,Ordu, K.Maraş, & 9 & Diyarbakır & 2 & Şanlıurfa & 2 \\
\hline \multicolumn{6}{|l|}{ Hatay, Eskişehir, Bursa, Balıkesir, } \\
\hline \multicolumn{6}{|l|}{ Antalya } \\
\hline & & Antalya & 2 & Diyarbakır & 2 \\
\hline & & Her ilde I büro & 16 & Bursa & 2 \\
\hline & & & & Her ilde I büro & 23 \\
\hline
\end{tabular}

(BAP Anket Verileri-2019). BAP: Bilimsel Araştırma Projesi.

planlama bürolarının sayılarında artışa neden olmuştur (ŞPO 29. Dönem Çalışma Raporu, 2016-2018).

Serbest planlama büroları Ankara, İstanbul, İzmir gibi büyük kentlerde yoğunlaşmıştır. Ankara \%/8'lik oran ile Türkiye'de en fazla planlama bürosuna sahip kent olarak birinci sırada iken, Ankara'yı sırasıyla \% 15 ve \%7'lik oran ile İstanbul ve İzmir izlemektedir (ŞPO Tescilli Şirketler Listesi, 2018, Şekil I). Bursa (\%4), Antalya (\%3.8), Muğla (\%3.5) ve Konya (\%3.5) ise İstanbul ve İzmir'den sonra en çok planlama ofisine sahip kentlerdir (ŞPO Tescilli Şirketler Listesi, 2018). Planlama bürolarının ağırlıklı olarak Ankara'da yer almasının temel nedeni planlamanın merkeziyetçi yapısı ve kamu kurumlarının genel merkezlerinin başkentte olması iken, diğer planlama bürolarının özellikle Batıda ve kıyı kentlerinde yoğunlaşması bu kentlerin ekonomik gelişmişlik düzeyi ve ilk dönem planlama okullarının bu kentlerde yada yakın çevresinde yer alması ile ilişkilidir. Türkiye'de sosyo ekonomik gelişmişlik endekslerinde altlarda kalan toplam sekiz ilde ise serbest planlama ofisi bulunmamaktadır (Bartın, Ardahan, Bayburt, Bilecik, Gümüşhane, Hakkari, Kars, Kilis) (ŞPO Tescilli Şirketler Listesi, 2018).

119 serbest planlama bürosu ile gerçekleştirilen ankete göre 2000 öncesinde büroların Ankara, İstanbul ve İzmir başta olmak üzere nispeten büyük kentlerde kurulduğu, 2000 sonrasında ise aşamalı olarak Türkiye'nin her yerine dağıldığı, ancak halen büyük kentlerin bürolar için cazibesini koruduğu görülmektedir (Tablo I, 2). Kentleşme hızının yüksek ve gayrimenkul piyasasının dinamik olduğu bu kentlerin iş potansiyeli piyasaya yeni giren genç plancılar için daha çok firsat sunmaktadır. Nitekim, Türkiye'de planlama bürolarının en çok iş yaptığı şehirler de ekonomik gelişmişlik düzeyi yüksek Bursa, İstanbul, Antalya, İzmir, Ankara ve Kayseri gibi kentlerdir (MDU, 2003-2018). Planlama bürolarının en az iş yaptığı şehirler ise yine ekonomik anlamda geri kalmış Bayburt, Bingöl, Tunceli, Kars, Aksaray, Artvin, Ardahan, Hakkari, Kırıkkale ve Gümüşhane’dir (MDU, 2003-2018).

Türkiye'de planlama sektörü karne sistemine göre düzenlenmiştir. Karne yönetmeliği ilk defa 1969'da yayınlanan "İmar ve Yol İstikamet Planlarının Tanzim Şartları ile Teknik Şartlarına ve Bu İşleri Yapacak Uzmanlarda Aranacak Ehliyete Dair Yönetmelik" tarafından belirlenmiştir (Kıral, 2010). Plan yapacakları A, B, C, D, E, F olmak üzere altı gruba ayıran bu yönetmelik 1985'te ve 2006 'da iki kez değiştirilmiştir. Her karne grubu belli ölçek ve nüfus büyüklüğündeki yerleşmenin planlanmasına dair iş tanımı ile sınıllandırımış, karne yükseltme ise alt karne grubunda bitirilen iş sayısı ile tanımlanmıştır. Türkiye'deki planlama bürolarının \%20'si A grubu, \%4'ü B grubu, \%8'i C grubu \%।3'ü E grubu ve \%48'i $F$ grubudur (ŞPO Tescilli Şirketler Listesi, 20 I8). Bürolar arasında F grubu planlama bürolarının tüm planlama bürolarının \%48'ini oluşturması son yıllarda yeni mezun sayısındaki artış, kamuda kısıtı iş 


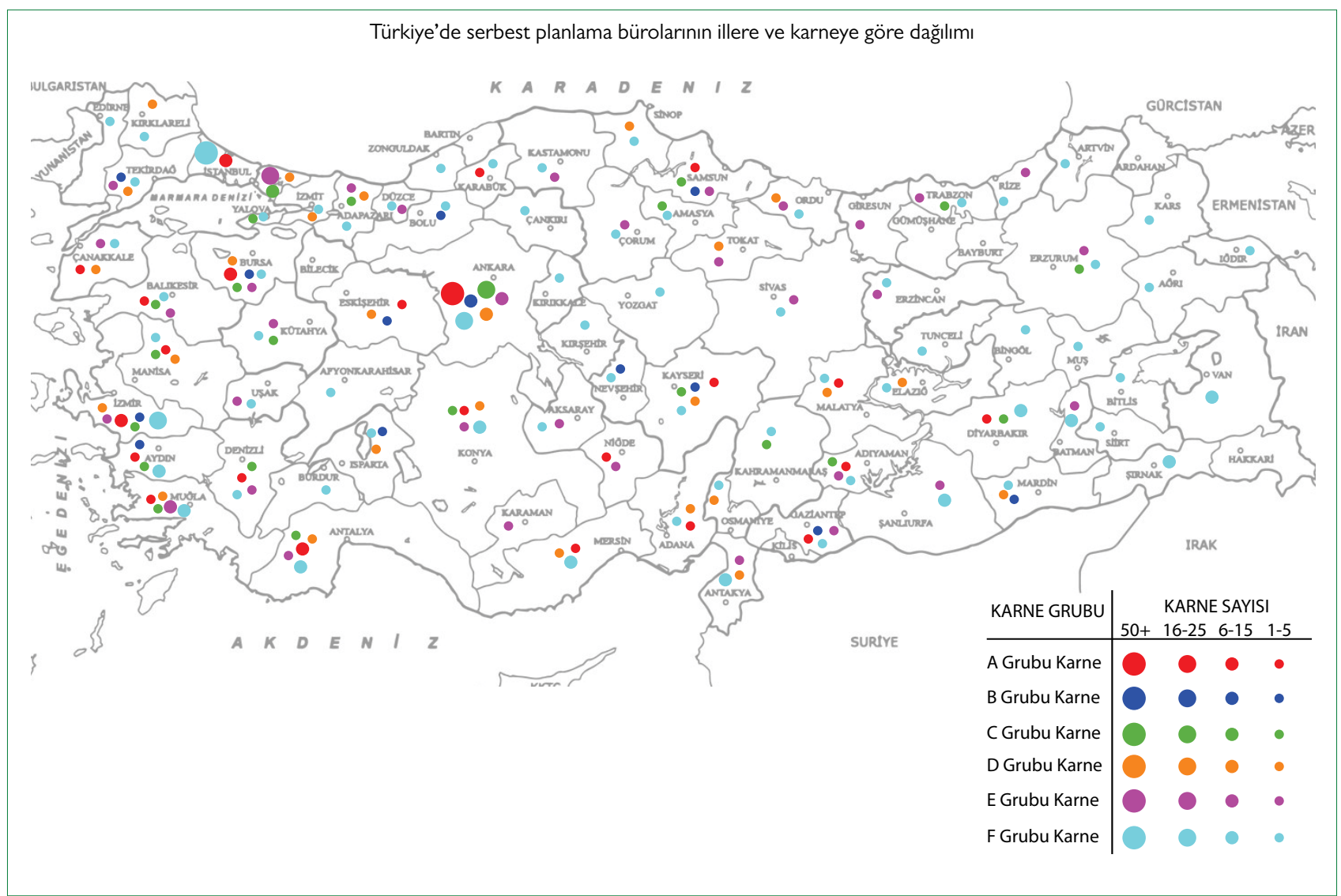

Şekil 2. Türkiye'de ŞPO'ya tescilli planlama bürolarının karnelere ve şehirlere göre dağılımı (ŞPO-20।8).

ŞPO: Şehir Plancıları Odası.

imkanları ve yeni mezunların serbest çalışmaya yönelmesi nedenleriyledir. A, B ve $C$ grubu büro sayısının en yoğun olduğu kent Ankara'dır (Şekil 2). Yukarıdaki şekilde de görüldüğü gibi sırasıyla A grubu büroların \%40'ı, B grubu büroların \%33'ü, C Grubu büroların \%32'si Ankara'da faaliyet göstermektedir. Hem ilk planlama bürolarının Ankara'da kurulmuş olması, hem de 2000'lere kadar planlama sektöründe iller Bankasının belirleyici olması, hem de özellikle 1990'lardan itibaren merkezi yönetime ait birçok kuruma plan yapma ve onama yetkisi verilmesi gibi nedenlerle, Ankara planlama büroları için cazibesini her zaman korumuştur. $E$ ve $F$ grubu firmaların en yoğun olduğu kent ise İstanbul'dur. E grubu firmaların \%2l'i, F grubu büroların \%।8'i İstanbul'dadır (ŞPO Tescilli Şirketler Listesi, 2018). Ancak F grubu firmalar sekiz kent dışında (Bartın, Ardahan, Bayburt, Bilecik, Gümüşhane, Hakkari, Kars, Kilis) tüm kentlere yayılmışlardır (Şekil 2).

Ankara'daki planlama büroları Türkiye'nin hemen hemen tüm şehirlerinde iş yapabilirken, diğer şehirlerdeki planlama bürolarının bir bölümü bölgesel ölçekte bir bölümü ise sadece oldukları kentte varlık gösterebilmektedir. Ankara'daki bürolar Ankara dışında, Kayseri, Zonguldak, Yozgat, Van, Şanlıurfa, Mardin, Kırşehir, Erzurum, Diyarbakır ve Afyonkarahi- sar illeri başta olmak üzere oldukça geniş bir coğrafyada iş alabilmektedir (MDU, 2003-20I8). Bu büroların bir kısmının belirli kentlerde hegemonyalarını kurdukları gözlemlenmektedir. Kayseri'deki toplam işin \%96'sı, Diyarbakır'da \%50'si, Hakkâri'de \%70 ve Tokat da \%70'i Ankara'dan tek firma tarafından yapılmaktadır (MDU, 2003-2018). Ancak İstanbul da dahil olmak üzere diğer şehirlerdeki firmalar ağırlıklı olarak kendi kentlerinde ya da yakın coğrafyalarında faaliyet göstermekte, nadiren de olsa kendilerine yakın olmayan kentlerde de iş yapabilmektedirler. Örneğin 2003 ile 2018 yılları arasında İstanbul'daki planlama ofislerinin yaptıkları işlerin \%94'ü İstanbul'dadır (MDU, 2003-2018). İstanbul dışında ağırııkı olarak Tekirdağ, Kocaeli, Kırklareli, Diyarbakır ve lğdır illerinde iş yapmışlardır. Iğdır, Ardahan, Ağrı ve Kars'ta İstanbul'dan tek bir firma üzerinden iş yoğunluğu dönerken Kocaeli, Edirne, Sakarya ve Tekirdağ'da ise İstanbul'dan iki firma üzerinde yoğunlaşmıştır (MDU, 2003-2018). Yine Adana'daki bürolar ağırlıklı olarak Adana, Hatay, Osmaniye, Mersin'de; Antalya'daki bürolar Antalya, Burdur, Isparta; Aydındaki bürolar Aydın, İzmir; Diyarbakır'daki bürolar Diyarbakır, Batman, Bitlis, Mardin, Elazığ, Siirt'te; Malatya'daki bürolar Malatya, Tunceli, Elazı̆̆, Mardin, Sivas, Ĭğır, Muş ve Van'da iş yapmaktadırlar (MDU, 2003-2018). 
Hem en fazla sayıda planlama bürosuna sahip olduğu, hem de başta $A$ karne olmak üzere büyük karneye sahip büroların kentte yoğunlaşmış olması ve buradaki büroların Türkiye coğrafyasında iş yaptıkları alanın büyüklüğü Ankara'yı planlama sektöründe öne çıkartmaktadır. Büroların etkili oldukları coğrafyanın büyüklüğü iş piyasasında aldıkları payın büyüklüğüne de işaret etmektedir. Uzun süre önce piyasaya girmiş bu bürolar, belli bir sermaye birikimine ulaşmış ve piyasada hakimiyetlerini kurmuşlardır. Piyasadaki tanınırlıkları, mevzuata hakim olmaları ve güvenilirlikleri bu büroların işveren tarafından tercih edilmesinde etkili iken, karne sistemi piyasada büyük karne grubu planlama büroları lehine göreli bir tekelleşmeye imkan sağlamaktadır. Aşağıdaki ilk bölüm karne sisteminin planlama piyasasında yarattığı eşitsizlikleri ve piyasanın karne sisteminin kısıtlamalarından kurtulmak için ürettiği mekanizmaları tartışmaya açacaktır. İzleyen bölümde ise planlama büroları arasında karne grubu, kuruluş yılı ve bulundukları coğrafyaya göre planlama işinin nasıl paylaşıldığı ortaya konulacaktır.

\section{Karne Sisteminin Plancılar Arasında Yarattığı Kategorik Ayrım}

Türkiye'de mekânsal planların elde edilmesine ilişkin yönetmeliklerde müelliflerde aranacak niteliklere ilişkin temel kriter deneyim olarak belirlenmiştir. Karne sistemi 1969 senesinde çıkarılan yönetmelikle belirginleşmiş, 1985 yönetmeliği ile karne gruplarına nüfus büyüklüklerinin yanında alan büyüklüğü kriteri de getirilmiştir. ${ }^{4} 1969$ yönetmeliğinde metropol kentlerin planlaması karne sınıflandırması sistemi dışında bırakılmışken, 1985 ve 2006 yönetmeliklerinde metropol kentlerin planlaması da yeterlilik yönetmeliği kapsamına alınmıştır (Kıral, 20I0). ${ }^{5}$ Ancak karne yönetmeliği daha baştan itibaren planlama işini yapacakların geçmiş deneyimi yanında planlama hizmetini yapacak uzmanların nitelikleri, teknik ekibin yapısı, planlama konusuna nasıl bir teknik yaklaşımında bulunulacağı gibi konuların yeterince ele alınmaması, kentlerin farklı niteliklerinin göz ardı edilmesi gibi konularda eleştirilmiştir (Kıral, 2010). Kentleşme dinamiklerindeki yeni eğilimler, planlamada yeni paradigmaların ortaya çıkması, kentsel dönüşüm gibi çok disiplinli bir süreç yürütmeyi zorunlu kılan planlama konularının ortaya çıkması gibi meseleler ise yalnızca tecrübe ile işlerin yürütülebilmesini imkansız kılmaktadır.

Diğer taraftan deneyim üzerinden gerekçelendirilen karne sistemi serbest planlama büroları arasında, kamuda ya da akademide çalışan plancılar ile serbest piyasada çalışan plancılar arasında eşitsizlikler yaratmaktadır. Türkiye'de karne yönetmeliğinde müellifliğe ilişkin son düzenleme 2006 yılında yapılmış, bu yıla kadar mimarların karne sistemine girmeleri mümkünken, 2006 yönetmeliği ile mimarların kazanılmış hakları saklı kalmak kaydıyla, sadece üniversitelerin şehir ve bölge planlama bölümlerinden mezun olanlara plan yapma yetkisi verilmiştir. Piyasada mimar plancıların sayısı azalırken, şehir plancılarının hakimiyeti artmıştır. Ancak katılaşarak uygulamaya devam eden karne yönetmeliği daha ilk çıktığı yıllardan itibaren genç plancıların sektöre girişlerini zorlaştırmış, farklı karne gruplarındaki bürolar arasında piyasadan aldıkları pay anlamında eşitsizlikler yaratmıştır (Tekeli, 1987). Özellikle 2000 sonrasında artan rekabet koşullarında ise karne yönetmeliğinden kaynaklı eşitsizlikler derinleşmiştir. ${ }^{6}$

ŞPO'nun dönem çalışma raporlarında sıklıkla ifade edildiği üzere karne yönetmeliği bürolar arasında eşit çalışma koşullarını engelleyici hükümler taşımaktadır. Karne yönetmeliğine göre yeni mezun olan bir plancı $F$ karne sahibidir ve iş yapabildiği ölçekler karne yönetmeliği ile sınırlandırılmıştır. Karne yükseltmede temel şart iş bitirmedir. Ancak her karne grubunun yapabileceği hizmetlerde üst sınır saptanmış olup alt sınır saptanmamış olması, üst grup plancıların kendilerinin altındaki diğer karne gruplarının kapsamına giren işleri de alabiliyor olması, piyasayı alt karne gruplarına doğru daraltırken, karne gruplarında üst sıralara doğru gittikçe piyasa da büyümektedir. Karne grupları arasındaki eşitsizlik 30 Mart 2014 tarihinde yürürlüğe giren 6360 sayılı yasa ile Büyükşehir Belediyesi olan 30 ilin idari sınırları içerisinde kalan her yerde, yapılacak her türlü imar planı, imar planı değişikliği, ilave ve revizyon imar planlarının yapımında sadece $(A)$ grubu yeterlilik belgesine sahip olan şehir plancılarının plan müellifi olabileceklerine dair kararla daha da büyümüştür (ŞPO 28. Çalışma Raporu, 20|4-20|6). ŞPO'nun itirazları sonucunda 2019'da düzeltilen bu karar geçen 5 yıllık süre içinde 30 büyük ilde $A$ grubu karne dışındaki diğer karne gruplarının iş yapmasını engellemiş, haksız rekabete yol açarak piyasayı alt grupların aleyhine daha da derinleştirmiştir (ŞPO, 2019). Üst karne gruplarının alt karne grubuna giren işleri yapabiliyor olması, ankete katılan plancıların \%62'sinin işaret ettiği gibi üst karne grubundaki planlama bürolarının tecrübe, sektörde tanınmak ve güvenilirlik, mesleki bilgi ve mevzuata hakimiyet gibi niteliklerinden dolayı iş alım sürecinde işveren tarafından tercih edilmesi alt karne grupları için piyasada varlığını sürdürmek, büyüyebilmek adına önemli engeller olarak ortaya çıkarmaktadır. Araştırma kapsamında yürütülen anket çalışmasında planlama bürolarının \%73'ünün de ifade ettiği üzere, Türkiye'de 2000 sonrasında planlama işi alabilmenin ve büyüyebilmenin başat koşulunun siyasi, bürok-

4 Karne yönetmeliğine ilişkin ilk düzenlemeler 1930'larda yapılmıştır.

5 Metropoller için önce Ankara, İstanbul, İzmir daha sonra Bursa, Samsun gibi diğer büyükşehirlerde nazım plan büroları kurularak ekip anlayışıla planlama yapılmıştır.

6 Karne yönetmeliğine ilişkin şehir plancıları odasının yapmış olduğu tartışmaya bu noktada dikkat çekmek önemlidir. Şehir Plancıları Odası, mezun plancılar için hiçbir meslek dalında olmayan bu hiyerarşik durumu eleştirilmektedir. Diğer yandan özellikle A karne sahibi plancıların tek başına metropolü planlama yetkisinin bulunmasına da bu bağlamda eleştirel yaklaşmakta, özellikle disiplinlerarası olmanın, takım çalışmasının çok önem kazandığı günümüz dünyasında ekibe değil yalnızca yıl bazında iş yapmış olmaya bu kadar önem atfetmenin yanlışlığının altını çizer. Plancıları sınıflamak yerine bölgelerin, kentlerin sınıflandırılmasını ve her bir sınıfa yönelik farklı ekiplerin tanımlanması gerekliliğini vurgular. Böylelikle tecrübeli veya tecrübesiz plancıların ya da farklı disiplinlerden kişilerin bulunduğu ekiplerle planlamanın daha doğru olacağı görüşünü savunur. 
ratik tanıdıklık ve belli siyaset/sermaye çevrelerine yakınlık olması piyasaya yeni giren plancıları karne sisteminin getirdiği sınırlandırmalar ile siyaset-sermaye-bürokrasi üçgeninde ilişki geliştirme arasında sıkışırımaktadır.

Karne yönetmeliğinin yol açtı̆̆ı diğer bir eşitsizlik alanı ise kamuda yada akademide belli süre çalışmış plancıların A karne grubunu hakkederek emekli olup başka bir plancı ile yada tek başına planlama bürosu açması ya da karnesini kullanarak yapım sürecinde aktif olarak rol almadığı planlara imza atması yani karnesini kiralaması ile ortaya çıkmaktadır. Serbest çalışan plancılar ile kamuda çalışan plancılar arasında önemli bir kategorik ayrım yaratan bu durumdan rahatsız olan serbest büro sahibi plancılar, kamuda bilfiil plan yapmak yerine daha farklı, geri plan işlerde çalışmasına rağmen hızlı bir şekilde karnesini yükselten plancılarla yıllarca piyasada çalışanlar arasında önemli bir fark olduğunu belirtmektedirler.

"En başta yaşadı̆̆ımız sıkıntılardan biri de karne mevzusudur. Memuriyetteki arkadaşlarımız kolaylıkla $A$ karnelere ulaşabiliyorlar. Biz bu zamana kadar kaç bin hektar iş yaptık fakat $A$ karne değiliz. Şirketimizde $A$ karne ile çalışan 2 arkadaşımızda var." (Büro J)

"A grubu karneli plancı (kamudan emekli), planlamayı hiç yapmamış oluyor. Şimdi kuyumcu düşünün. Şu yüzüğü yaparsınız. Siz yapıyorsunuz, ben de satıyorum. Şimdi siz bundan 700 tane yapmalısınız ki ustalık belgenizi alabilesiniz. Ama bu 12 senede 3 tane de gelmiş olabilir, I tane de gelmiş olabilir. $O$ (kamuda yıl sayısıyla karnesi yükselen plancı) A grubu alıyor, siz (serbest büro çalışanı plancı) alamıyorsunuz." (Büro E)

Tekeli'ye (1987) göre F grubu bir plancının A grubu olabilmesi için gerekli süre ortalama 20 yıldır. Tekeli'nin bu tespiti üzerinden 30 yılı aşkın zaman geçmesine ve değişen piyasa koşullarına rağmen derinlemesine görüşme yapılan bürolar karne yükseltmede benzer sürelere işaret etmişlerdir. İstanbul'da en çok iş yapan ve 23 yıldır aktif olarak piyasada çalışan, Çevre Düzeni Planı yapmış planlama bürosu Büro K hala B karnesine sahip iken, 32 yıldır aktif olarak çalışan ve İstanbul Çevre Düzeni Planının Revizyonunu yapan Büro D ise hala D karne sahibidir. Yine bürosunu 1990'larda açmış, planlama piyasasında farklı türlerde birçok iş almış büro hala A karne grubu olamamıştır. Benzer bir durum Anadolu'daki diğer kentlerde bölgesel hakimiyetini kurmuş olan planlama büroları için de geçerlidir.

Piyasada karne yönetmeliğini aşarak iş alabilmek için üç farklı yöntem gelişmiştir. Bu yöntemlerden bir tanesi $A$ karne sahibi bir plancıyı geçici istihdam ederek $A$ karne gerektiren işleri alabilir hale gelmektir. ${ }^{7}$ Bu yöntem yaygın olarak özellikle B ve $C$ grubu karneye sahip bürolar tarafından kullanılmaktadır.
Görüşme yapılan $\mathrm{H}$ bürosu işlerini $\mathrm{A}$ grubu karne sahibi bir tanıdığına imzalattığını söylemiş̧ir:

"Mesela ben $B$ grubu plancıyım. Inşallah $I-2$ ay içinde Bakanlık'a dosyamızı sunacağız, A olacağız. Ama ben bile mesela Ankara'daki işlerimi A grubundaki bir arkadaşıma imzalattırıyorum." şeklinde belirtmektedir.

Bu A grubu karne sahibi plancı kamudan emekli olmuş ya da piyasada aktif olarak çalışan plancı olabilmektedir. Hem ŞPO Genel Başkanı hem de ŞPO İstanbul Şube Başkanı ile yapılan görüşmede, hem de bürolarla yapılan görüşmelerde karne kiralama meselesine vurgu yapılmış, bu plancıların bazılarının belli bölgelerdeki birçok işe imza attıklarını, bazılarının ise plandan habersiz olduğunun altı çizilmiştir (Sarıaltun, 2018; Kahraman, 2018).

"A grubu karnesini almış, ondan sonra kiraya veriyor. Yaptığı plandan haberi bile yok, sorsan bilmez. İmza atıyor sadece." (Büro E)

“...bölgede çok etkili olan $X X$ adında $A$ grubu karne sahibi olan biri var. $O$ imza üzerine çalışan bir arkadaş.” (Büro $R$ )

İkinci yöntem ise, A karne sahibi planlama bürosu tarafından alınan işin taşeronluğunun genellikle $E$ ya da $F$ grubu bir planlama bürosu tarafından yapılması ya da bürolar arasında iş bazında ortaklıklara gidilmesidir. Türkiye'deki planlama bürolarının büyük bir çoğunluğu mikro ölçekte firmalardan oluşmaktadır (BAP, 2018). Anketlere göre Türkiye'deki büroların \%57'si I kişi, \%25'i 2-3 kişi, \%।3'ü ise 4-6 kişi istihdam etmektedir. İ̧ yoğunluğuna bağlı olarak bürolar geçici istihdama gidebilmekte, ancak taşeron usulü yada ortaklaşa çalışmayı daha çok tercih etmektedirler. Özellikle piyasaya yeni giren serbest plancılar taşeron usulü çalışmakta iken, ortaklıklar ise daha çok eski bürolar arasında yine plan bazında kurulabilmektedir. Karne derecesi yüksek bürolar bir işi almakta, daha sonra bu işi ya da işin bir kısmını, karne veya iş yapma deneyimi sebebiyle bu işi alamayan yeni bürolara aktarmaktadır. Yalnızca planlama işi değil planlamayı destekleyen harita sayısallaştırma, analiz işleri gibi diğer faaliyetlerde de taşeron sistemi işlemektedir. Bu anlamda iki farklı iş kaleminin taşerona verildiği görülmektedir. Bunlardan biri, büyük, deneyimli ama klasik iş yapma kültürü olan büroların elindeki büyük işlerin bir kısmını daha genç, teknolojiyi kolay kullanan yeni bürolara vermesi, ikincisi ise doğrudan plan işlerinin yine bir önceki başlıkta da belirtildiği gibi daha düşük karneli büroları verilmesidir.

“94-95'lerde planlamada bilgisayar kullanımı artmaya başladı. ilk giren ofislerden birisiyim. O zaman Netcad yeni kullanılmaya başlanmıştı. Planlamada çok yaygınlaşmamıştı. Haritacılar kullanıyordu daha çok. ilk işlerimiz bunlardı." (Büro F)

\footnotetext{
7 ŞPO'ya kayıtlı Serbest Şehircilik Bürolarının karne grubu çoğunluk hissesine sahip şehir plancısının plan yapım yeterlilik belgesine göre belirlenmektedir.
} 
"Netcad ve GIS yetmiyor. O zaman biz diyoruz bir yazılımcıyla anlaşalım diye. Eski ofisler çok böyle masraflara girmiyorlar. Hepsi için demiyorum. Böyle işleri taşero ediyorlar bazıları." (Büro $P$ )

“Bizim Ankara ve İskenderun'da da şubelerimiz var. Taşeronumuz da var. Fakat planlama değil farklı sektörlerde.” (Büro J)

"Ofiste 25 kişinin üzerine çıkmamak hedefleniyor. Kadroyu büyütmek yerine taşeron sistemi kullanılıyor.” (Büro D)

Karne yönetmeliğinin getirdiği tüm engellere rağmen planlama bürolarının büyümesi asıl olarak 2003 ile 2018 arasında inşaat sektörünün önünü açmak için yasal ve yönetsel düzenlemelerle yaygınlaştırılan parçacıl planlama uygulamaları, büyüyen gayrimenkul sektörünün doğurduğu gayrimenkul danışmanlığı, 2000'lerin başlarından itibaren tüm hükümetlerin neredeyse tek politikası haline gelen kentsel dönüşüm uygulamaları ve inşaat sektöründe rant arayışını yükselten sermaye gruplarına danışmanlık gibi çeşitlenen işlerle mümkün olmuştur. İzleyen bölümde detaylandırılacağı üzere 2003 ile 2018 arasında plan değişikliği piyasaya yeni giren plancıların neredeyse tamamı, diğer karne gruplarının ise birçoğu tarafından en yoğun yapılan iş iken, yeni ortaya çıkan diğer iş alanları büroları finansal devamlılıklarında önemli rol oynamıştır. Böylece 2000'lerle birlikte planlama büroları Türkiye'nin hemen her yerine yayılırken, iş piyasası da önceki yıllara göre hem büyümüş hem de çeşitlenmiştir. İzleyen bölüm işin niteliğindeki bu dönüşümü analiz edecektir.

\section{Büroların ve Yapılan İşlerin Nicel ve Nitel Değişimi}

Türkiye'de yaklaşık yüz büro salt imar planı işi yapmaktadır (Sarıaltun, 2019). Şehir Plancıları Odası Genel Başkanı Sarıaltun'a (20I8) göre büroların bir kısmı inşaat, gayrimenkul değerleme gibi işler yapmakta planlamayı ise bir yan uğraş olarak görmektedir. Sadece kentsel tasarım, koruma, kentsel dönüşüm gibi uzmanlık isteyen işlere yoğunlaşan firmalar sayıca daha az olup, bu tarz büroların da önemli bir bölümü Ankara ve İstanbul'da yer almaktadır (Sarıaltun, 2018). Mekansal planlama piyasasının büyük olmaması, piyasada serbest şehircilik hizmeti veren plancıların sayılarındaki artış, bürolar arasındaki rekabet sonucu aşırı kırılan ihale bedelleri ya da ihale süreçlerinde yaşanan usulsüzlükler büroları varlıklarını sürdürebilmek veya büyüyebilmek için planlama ile birlikte gayrimenkul değerleme, haritacılık, özel sektöre danışmanlık, inşaat, mimarlık, gibi farklı faaliyetlere yöneltmiştir.

Türkiye'deki planlama bürolarının yaptıkları işler ŞPO tarafından tanımlanmış ve mesleki denetim uygulamasından geçmesi zorunlu tutulmuştur. Makalenin bu bölümü serbest şehircilik bürolarının yaptıkları işlerin analizini hedeflediği için başvuru- lan ilk kaynak 2003 ile 2018 yılları arasında tüm Türkiye'de mesleki denetimden geçen toplam 65 53I işin analizi, diğer kaynaklar ise Türkiye'de toplam 727 büronun II9'u ile yapılan anketlerden ve serbest planlama büroları ile yapılan görüşmelerden elde edilen verilerdir.

Türkiye'de 2003 ile 2018 yılları arasında yapılan tüm işlerin karne grupları arasında paylaşımına bakıldığında A grubu karne sahibi büroların özellikle de Ankara'da faaliyet gösteren A grubu büroların piyasada egemenliğini koruduğu görülmektedir. A grubu planlama büroları 2003 ile 2018 arasında MDU'ya konu olan işlerin \%27'sini yapar iken, şehircilik hizmet türlerinin hepsinde, özellikle de büyük ölçekli ya da sektörel planların yapımında en büyük paya sahiptir (Tablo 3). I/I00000 ve I/50000 ölçekli Bölgesel, İl yada Havza Düzeyinde yapılan Çevre Düzeni Planlarının \%73'ü, Kentsel Sit Koruma Amaçlı İmar Planlarının \%70’i, Kentsel Sit Koruma Amaçlı İmar Planı Değişikliklerinin \%5।’i, Çevre Düzeni Plan Değişiklilerinin \%39'u, Kent İçi Ulaşım Projelerinin \%50'sinin A grubu planlama büroları tarafından yapılmıştır (Tablo 3). Üst ölçekli planlar, sektörel planlar ve kentsel tasarım projelerinin büyük bir kısmı Ankara'daki üst karne grubu planlama ofisleri tarafından gerçekleştirilirken, İstanbul'daki bürolar uzmanlık gerektiren bu plan türlerinde Ankara ile karşılaştırıldığında büyük bir varlık gösterememiştir. Türkiye'de yapılan Çevre Düzeni Planlarının \%45’i, Kentsel Sit Koruma Amaçlı İmar Planlarının \%73’ü, Koruma Amaçlı İmar Planlarının \%38'i, Arkeolojik ve Tarihi Sit Koruma Amaçlı İmar Planlarının \%47'si Ankara'daki bürolar tarafından yapılmış iken, İstanbul'daki bürolar ise Çevre Düzeni Planlarının \%6'sını, İmar Planlarının \%8'ini, Uygulama İmar Planlarının \%8'ini, Koruma Amaçlı İmar Planlarının \%।6'sını, Arkeolojik ve Tarihi Sit Koruma Amaçlı İmar Planlarının \% I'ini ve Kentsel Sit Koruma Amaçlı İmar Planlarının \%।'ini yapmıştır (Tablo 3). Ayrıca, Türkiye çapında 2003 ile 2018 yılları arasında yapılan Nazım ve Uygulama İmar Planlama işlerinin \%30'u, plan değişikliği işlerinin \%30'u Ankara büroları tarafından yapılmıştır.

MDU verilerine göre Türkiye'de 2003 ile 2018 yılları arasında yapılan tüm mekansal planlama işlerinin \%78'i 'imar planı değişikliği’, \%20'si ‘Nazım ve Uygulama İmar Planı'dır. Tüm karne gruplarının yapmış olduğu şehircilik hizmetlerinin \%75'den fazlası “Plan Değişiklikleri” ne aittir (Tablo 3). İnşaat sektörünün ekonominin başat sektörü haline gelmesi, toplumun hemen her kesiminin artan rant beklentisi ve pek çok kentsel projenin ortaya çıkması plan değişikliklerini de beraberinde getirmiştir. Plan ve plan değişikliklerinin yapım ve onaylama yetkisinin 1985'de yürürlüğe giren 3194 sayılı İmar Kanunu ile yerel yönetimlere verilerek merkezi yönetimin süreç dışında bırakılmasıyla bürokratik işlemler büyük ölçüde kolaylaştırılmış ve yeni düzenleme ile plan değişiklikleri sayısında ciddi ölçülerde artış olmuştur. İmar planı değişikliklerinin merkezi yönetim tarafından onaylandığı I965-I978 
Tablo 3. Türkiye'deki planlama ofislerin yaptıkları plan türleri

\begin{tabular}{|c|c|c|c|c|c|c|c|c|}
\hline Plan türleri & A grubu & B grubu & C grubu & D grubu & E grubu & F grubu & Bilinmiyor & Toplam \\
\hline ÇDP & 102 & 1 & 8 & 13 & 3 & 4 & 7 & 138 \\
\hline ATKAIP & 14 & - & 4 & 3 & 4 & 2 & 7 & 34 \\
\hline ÇDPD & 70 & 9 & 19 & 22 & 19 & 19 & 22 & 180 \\
\hline Danışmanlık hizmetleri & 6 & - & - & 4 & 7 & 2 & $\mathrm{I}$ & 20 \\
\hline DSKAIP & 10 & - & 2 & 3 & 8 & 4 & 4 & 31 \\
\hline Plan değişikliği & 13700 & 4315 & 5833 & 4803 & 5923 & 9756 & 6665 & 50995 \\
\hline İmar planları & 696 & 320 & 343 & 390 & 357 & 668 & 197 & 2971 \\
\hline KUP ve SP & 13 & $\mathrm{I}$ & 5 & I & 3 & 3 & - & 26 \\
\hline KDP & 9 & - & 4 & I & 6 & 4 & 5 & 29 \\
\hline KSKAIP & 21 & - & 2 & I & - & 2 & 4 & 30 \\
\hline KSKAIPD & 30 & 3 & 5 & 6 & 9 & I & 5 & 59 \\
\hline KTP & 29 & 6 & 15 & 7 & 12 & 23 & 7 & 99 \\
\hline KAIP & 138 & 23 & 23 & 22 & 35 & 30 & 21 & 292 \\
\hline KGP & 7 & 6 & 5 & 9 & 13 & II & 14 & 65 \\
\hline NiP & 257 & 30 & 114 & 11 & 60 & 161 & 122 & 755 \\
\hline Plan notu değişikliği & 90 & 18 & 11 & 16 & 19 & 26 & 17 & 180 \\
\hline UiP & 2144 & 893 & 1324 & 1102 & 989 & 1510 & 1639 & 9601 \\
\hline BKAY & 2 & - & 1 & - & - & - & - & 3 \\
\hline Master plan & 12 & - & - & - & - & - & - & 12 \\
\hline Gelişim planı & 10 & - & - & - & - & - & I & II \\
\hline
\end{tabular}

Kaynak: TMMOB ŞPO-MDU verileri 2003-2018. ŞPO: Şehir Plancıları Odası; MDU: Mesleki Denetim Uygulama; ÇDP: I//00.000 ve I/50.000 ölçekli; Bölgesel, il ya da Havza Düzeyinde Çevre Düzeni Planı; ATKAiP: Arkeolojik ve Tarihi Sit Koruma Amaçı İmar Planı; ÇDPD: I/I00.000 ve I/50.000 ölçekli; Bölgesel, il ya da Havza Düzeyinde Çevre Düzeni Planı Değişikliği; DSKAiP: Doğal Sit Koruma Amaçııı İmar Planı; KUP: Kent İçi Ulaşım Etütleri; SP: Ulaşım Ana Planları vb, Mekansal Etüt ve Sektörel Planlar; KDP: Kentsel Dönüşüm Planları ve Projeleri; KSKAiP: Kentsel Sit Koruma Amaçıı İmar Planı; KSKAiPD: Kentsel Sit Koruma Amaçlı İmar Planı Değişikliğ; KTP: Kentsel Tasarım Projeleri I/I000 ölçekli; KAiP: Koruma Amaçıı İmar Planı; KGP: Köy Gelişme Planları; NiP: Nazım İmar Planı (1/5000-I/25000); UiP: Uygulama İmar Planı (I/I000); BKAY: Bütünleşik Kıyı Alan Yönetimi.

yılları arasında Türkiye genelinde toplam 20787 adet plan değişikliği yapılırken (Günay, 1979: 34, aktaran Ersoy, 2000), MDU verilerine göre 2003 ile 2018 arasında toplam 50995 imar planı değişikliği yapılmıştır (Tablo 3). 3194 sayılı İmar Kanunu ve yönetmeliklerinde imar planlarında yapılacak değişikliklerin ancak yapılacak işle ilgili yeterlik belgesine sahip müellifler tarafından hazırlanabileceği koşulu gelmesine rağmen pratikte uzun süre bu göz ardı edilmiştir (Ersoy, 20l0). İşle ilgili yeterlilik belgesine sahip plancılara yaptırılmayan değişikliklere ilişkin yargı iptalleri sonrasında 1999 yılında yayımlanan "İmar Planı Yapılması ve Değişikliklerine Ait Esaslara Dair Yönetmelik"e ek madde getirilerek yasal zorunluluk açık hale getirilmiştir (Ersoy, 2000) İstanbul'da en çok iş yapan bürolardan Büro L'nin sahibine göre;

“istanbul'da dilekçeyle plan değişiyordu. Ali Müfit Gürtuna zamanında biri plan değişikliğini reddetme hakkı meclise aittir, müdürlük reddedemez diyerek Belediye'yi mahkemeye verdi ve kazandı. Belediye bu davadan sonra plan, planla değisirir ve müdürlük reddedemez yönünde karar aldı ve dilekçe kaldırıl- dı. Dilekçe kalkınca plan tadilatları sayısı arttı. Bundan sonra büro sayısı yükselmiştir. 2000-200I dönemlerinde.” (Büro L)

İmar planı değişikliği işi yaygın olarak piyasada ayakta kalmayı sağlayan en önemli kalemdir ve tüm karne grupları yoğun şekilde yapmaktadır. F grubu karne sahibi büroların yaptıkları tüm işlerin \%8l'ini oluşturduğu için bu büroların temel iş alanı imar planı değişikliğidir (Tablo 3). Ancak imar planı değişikliklerinde de en büyük payı yine $A$ grubu planlama büroları almaktadır. Türkiye'deki plan değişikliklerinin \%27'si A grubu planlama büroları tarafından yapılırken, \%8'i B, \% I l'i C, \%9'u $D$, \% I 'i E ve \% I9'u F grubu planlama büroları tarafindan yapılmaktadır (Tablo 3). Bu da bir önceki bölümde piyasaya yeni giren düşük karne grubuna sahip planlama bürolarının iş bulmadaki güçlüklerini açıklamaktadır.

Nazım ve Uygulama İmar Planlarında da tüm karne gruplarının birbirine yakın miktarda iş aldıkları görülmektedir. Ancak, araştırma kapsamında yapılan büro anketlerine göre $F$ grubu planlama bürolarının \%46'sı hiç imar planı yapmadığını belirt- 
miştir. Bu türde hiç iş yapmadıklarını beyan eden büroların tamamı ise 2000 sonrasında kurulan bürolardır. Bu oranlar F karne sahibi büroların çoğunlukla imar planı değişiklikleri yaptıklarını yada taşeron usulü çalışarak varlıklarını sürdürmeye çalıştıklarını yada ileride değinileceği üzere gayrimenkul değerleme, danışmanlık gibi işler yaptıklarını bir kez daha kanıtlamaktadır. Nazım ve uygulama imar planlarına ilişkin asıl ilginç olan konu ise dönem boyunca giderek artan plan revizyonlarıdır. Belediyeler yeni bir nazım ve uygulama imar planı yaptırmaktansa revizyon planı yaptırmayı tercih etmektedirler. Revizyon planların yaptırılma nedenlerinin başında parçacıl plan değişiklikleri ile plan bütünlüğünün bozulması ve birbirine entegre olmayan plan değişikliği kararları nedenleri ile uygulamada karşılaşılan güçlükler iken bir diğeri ise plan yapılacak alanda belli sermaye yada siyasi grupların rant beklentisidir.

"Şimdi yapılan ne biliyor musunuz ağırlıklı olarak? Bütüncül bir planlamada plan dışı gelişmeleri gittiğiniz zaman görüyorsunuz zaten. "Plan dışı gelişmeleri nasıl planlı hale getiririz?" aşamasına gidiyor olay. Revizyonların çoğu bu yüzden yapılıyor.” (Büro $H$ )

"Belediyeleri plan yapmaya iten temel motivasyon ise çoğu zaman belli bir sermaye grubunun yada bu grupla ilişkili siyasi grupların plandan rant beklentisidir" (Büro K).

Diğer taraftan yeni bir plan yapmak yerine var olan planda ufak değişiklikler yaparak revizyon oluşturmak genellikle belediyelere daha kârlı ve kolay gelmektedir. Ancak bu durum çoğu zaman detaylı analiz ve senteze dayanmayan revizyon planlarında ciddi sorunlar ortaya çıkmasına neden olmaktadır (Büro K, 2018).

Serbest şehircilik büroları tarafından gerçekleştirilen şehircilik hizmetlerindeki bu dönüşümle plan değişiklikleri, revizyon yada ilave planlarla parçacıl planlama piyasaya hakim olurken, aslında kamusal bir eylem olan planlamanın da işveren profilinin değişimini getirmiştir. 2003 ile 2018 yılları arasında gerçekleştirilen MDU verilerine göre, planlama bürolarının işvereninin\%56'sının özel sektör, \%44'ünün kamu sektörü olması çarpıcıdır. Özel sektör işverenleri şahıs ya da şirketlerdir ve çoğunlukla plan değişikliği ve/veya revizyon imar planları talep etmişlerdir. Kamuya yapılan işlerde ise en çok çalışılan işverenler belediyeler, il özel idareleri ve bakanlıktır (Şekil 3). 2000'lerin ortalarına değin plan yapım sürecinin en önemli kamu aktörü olan İller Bankasının işveren olarak payı azalmış, 3194 sayılı İmar Kanunun plan yapma ve onama yetkisini yerel yönetimlere devretmesi nedeniyle kamu kurumları arasında belediyelerin payı artmıştır. iller Bankasında 2004 ile 2018 yılları arasında toplam 1240 plan yapılmış, bu planların \%88'i ihale \%।2'si emanet yoluyla gerçekleştirilmiştir (Taşar, 20I8). Son yıllarda ise emanet yoluyla plan yapım işi sonlandırılmıştır (Taşar, 2018). Yine 1990'ların başlarından itibaren bir dizi yasal düzenleme ile plan yapmada yetkili kamu kurum ve kuruluşlarının sayısın- daki artış, planlama bürolarının iş aldıkları kamu kurumlarındaki çeşitliliği açıklar niteliktedir.

ŞPO'nun MDU verilerinde çok okunamayan, ancak bürolarla gerçekleştirilen anketlerde ve yarı yapılandırılmış görüşmelerde ortaya çıkan diğer bir konu ise serbest planlama bürolarının 1990'dan sonra sayısallaştırma, 2000'den itibaren ise gayrimenkul geliştirme ve değerleme, özel şirketlere danışmanlık ve kentsel dönüşüm alanlarında artan oranlarda faaliyet göstermeleridir (Şekil 4). Bu alanlarda yapılan işler kalem olarak az olabilse de getirisi kimi işlerde imar planı ihalelerini aşabilmektedir.

Planlama büroları ile İstanbul ve Ankara'da yapılan derinlemesine görüşmelerde bazı planlama bürolarının kendi şirketleri ile bağlantılı ayrı birer gayrimenkul şirketi, kentsel dönüşüm şirketi kurdukları tespit edilmiştir.

"Bu sektörle salt iş yaparsak biz de biteriz. Sadece çevre düzeni, imar planlarına odaklanırsak şirketin kendini devam ettirme imkanı yok. Sektöre, mesleğe de katkınız olmaz. Büro J olarak fabrika üretimi gibi entegre sistemler oluşturuyoruz. Bir taraftan planlamadan devam ederken bir taraftan da yurtdışındaki yatırımcılara gayrimenkul konusunda danışmanlık hizmeti veriyoruz. Yurtdısındaki yatırımcıların burada yatırım yapacakları yerlere müşavirlik hizmeti veriyoruz. Biz de buradaki projelerin planlarını yapıyoruz." (Büro J)

"Doğu'da rezerv alan önerileri yapıyoruz. Özel sektörle de iş yapıyoruz. Turizm şirketleriyle proje geliştiriyoruz.” (Büro P)

Türkiye gündemini en çok meşgul eden ve planlamanın neredeyse ana konusu haline gelen kentsel dönüşüm projelerinin yapımında ise özellikle büyük serbest planlama büroları öne çıkmaktadır. Araştırma kapsamında yürütülen ankete göre kentsel dönüşüm işi yapan büroların yoğun olarak bulunduğu kentler İstanbul, Ankara ve İzmir'dir (Şekil 5). 40 farklı kente dağılmış olan bürolar arasından bu üç kent toplam olumlu yanıtların \%35'ini kapsamakta, geri kalan kentlerde ise ya bu tür iş yapan büro bulunmamakta ya da $I$ tane büro nadiren bu işi yaptığını belirtmektedir.

"Biz inşaat firmalarına danışmanlık ve plan tadilatları yapıyoruz. Planlama ayağında devreye giriyoruz kentsel dönüşümde. Yapılanma koşullarının fizibilitesini yapıyoruz. Meri plan koşullarını ortaya çıkartıyoruz. Daha sonrada bu alanın dönüşebilmesi için vatandaşla müteahhidin yapmış olduğu anlaşmayla bu alanın dönüşebilmesi adına meri imar planında mevcut durumu tespit ediyoruz. Daha sonrasına plan tadilatına ihtiyaç varsa onu tespit ediyoruz. Bazen yapılanma koşulları uygun oluyor. Bazen plan değişmeden de dönüşüm gerçekleşebiliyor.” (Büro M)

Bürolar tarafından özellikle 2000'lerden sonra yapılmaya başlanan ve önemli ölçüde gelir getirici olan diğer işler ise yukarıda 


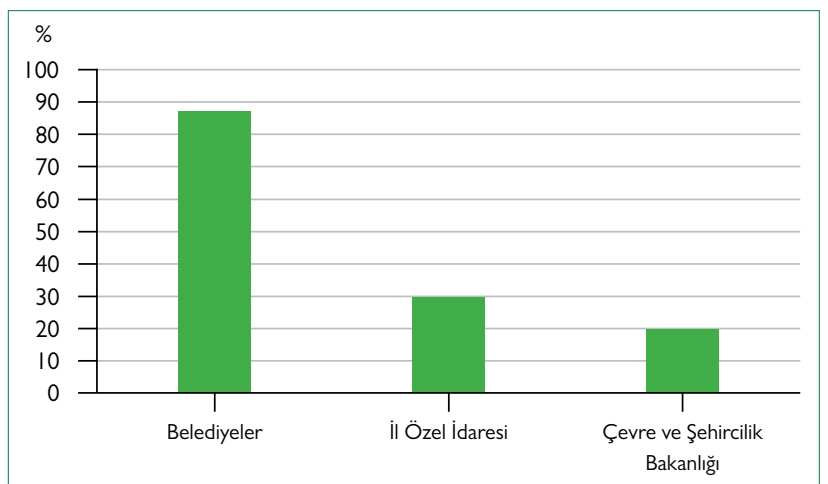

Şekil 3. Kamuda en çok karşılaşılan işverenler -MDU verileri 2003-20।8. MDU: Mesleki Denetim Uygulama.

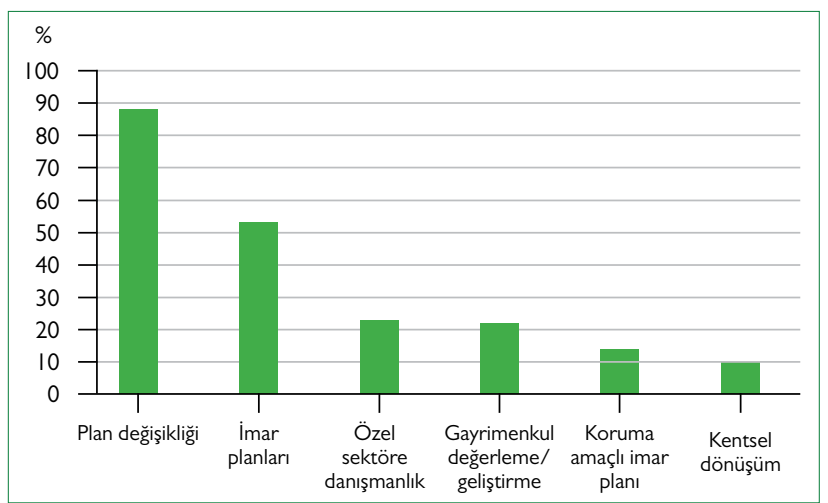

Şekil 4. Ankete katılan büroların yaptıkları işler (BAP anket verileri-20।8). BAP: Bilimsel Araştırma Projesi.

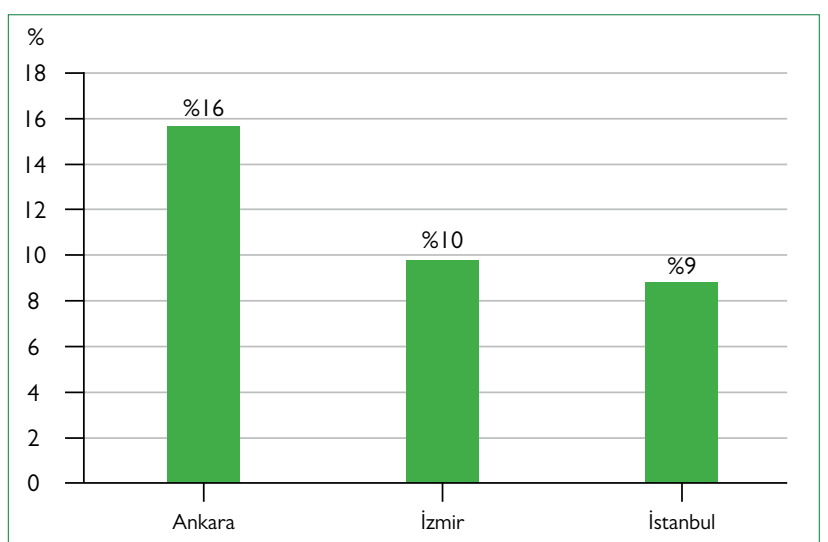

Şekil 5. Kentsel dönüşüm işlerinin 3 büyük kentteki yapılma oranları (BAP anket verileri-20 I8).

BAP: Bilimsel Araştırma Projesi.

da belirtildiği gibi gayrimenkul ve özel sektöre danışmanlıktır. Gayrimenkul değerleme işi özellikle büyük kentlerde yoğun biçimde piyasada yerini almasına rağmen, büroların \%68'inin bu türde iş yapmadıkları, \% I4'ünün ise çok yoğun olarak bu konu üzerine çalıştıkları görülmektedir (Şekil 6, 7). Bulundukları illere bakıldığında ise, gayrimenkul işi yaptığını beyan eden büroların 17 farklı ilde yer aldıkları, her ilde I büronun bu işi yaptığına dair beyanı varken Ankara, İstanbul ve İzmir'in bu konuda da öne çıktığı görülmektedir. Gayrimenkul konusunda az ya da çok çalıştığını beyan eden büroların \%94 kadarının 2000 yılından sonra kurulan bürolardan oluştuğu göze çarpmaktadır. 1990 yılından önce kurulan bürolardan hiçbiri bu işi yaptı̆̆ını beyan etmemiştir.

Karnelere bakıldığında da yine beklendiği gibi gayrimenkul değerleme işi yapan büroların \%73'ünün $\mathrm{F}$ karneye sahip oldukları görülmektedir. Diğer yandan gayrimenkul işi yapan büroların \%73'ü özel şirketlere danışmanlık da yapmaktadırlar. Bürolarla yapılan görüşmelerde gayrimenkul işleriyle kentsel dönüşüm işlerinin de paralellik gösterdiği belirtilmiştir. Kentsel dönüşüme yoğunlaşan büroların aynı zamanda gayrimenkul işi yaptıkları vurgulanmıştır.

"Bizimle aynı sektörde olan firmalar için kentsel dönüşüm geçilmek istenen bir alan gibi bu dönemde. Ama o işlerde çok uzun vadede tamamlanıyor. Onun içinde bu işi yapan firmaların ciddi bir finansmana ihtiyacı var. Bu nedenle başka işlerle de firmalarını döndürmeleri gerekiyor. Bir ara gayrimenkul değerleme konusu oldukça revaçtaydı. Plan konusunda çalışanlar daha büyük ofislere dönüşemiyor diye düşünüyorum.” (Büro I)

Şirketlere danışmanlık yapma işinin de büroların \%67'si tarafından gerçekleştirildiği, bu işi yapan şirketlerin ise yine \%77 kadarının 2000 sonrasında kurulduğu görülmektedir. 2010 sonrasında kurulan şirketler ise, 2000-2009 aralığında kurulan şirketlerden bile oransal olarak daha fazla bu işle uğraşmaktadır (Şekil 8). Şirket danışmanlığı işinde ise gayrimenkul işlerine göre farklılaşan durum, $A$ ve $B$ gibi yüksek karne grubundan büroların da bu işleri yapmasıdır. Anket verilerine göre, bu işi yaptığını beyan edenlerin \% I3 kadarı A karne büro olup, \%42'si ise A, B, $C$ gibi yüksek karne gruplarından oluşmaktadır. Şirketlere danışmanlık yaptığını beyan eden büroların yalnızca \%50'si F karneli bürodur ve bu oran gayrimenkul işlerindeki orana göre daha düşük kalmaktadır.

Yukarıdaki bulguların da işaret ettiği üzere 2000'lerle birlikte meslek alanına ilişkin piyasa büyümüş, yapılan işler çeşitlenmiştir. Ancak Zorlu'nun (2008) da işaret ettiği üzere gayrimenkul değerleme, sektörel yatırım projeleri, yatırım danışmalı̆̆ı, il gelişim planları, kırsal kalkınma planları gibi meslek uygulama alanı içinde yeni iş alanları kuramsal, örgütsel ve yasal düzlemlerde yeterince tanımlanmamıştır.

\section{Sonuç}

Türkiye'de 1980 sonrası izlenen neoliberal politikalarla uygulanmaya başlayan inşaat odaklı büyüme stratejileri, 2000 sonrasında neredeyse tüm toplumsal kesimlerin mutabakatını alarak yaygınlık kazanmıştır. Kentsel topraktan elde edilen rantın küçük büyük her ölçekte yatırımcı tarafından sermaye birikim araçlarından biri olarak keşfedilmesi, kamu kurumları 


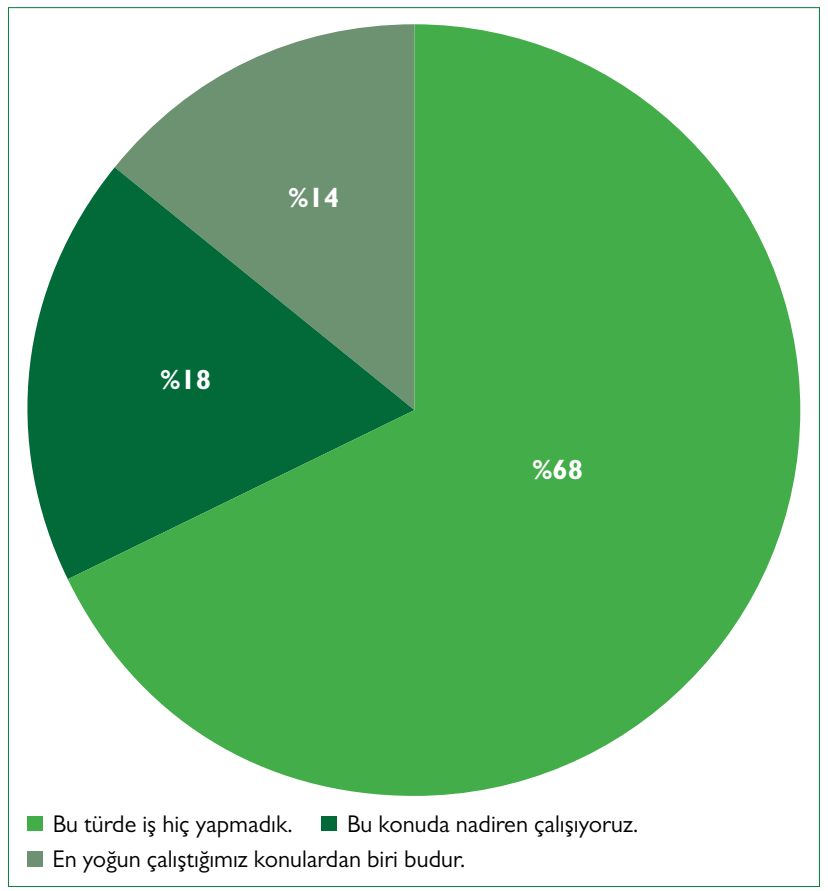

Şekil 6. Gayrimenkul değerleme işi yapma durumu (BAP anket verileri-20।8) BAP: Bilimsel Araştırma Projesi.

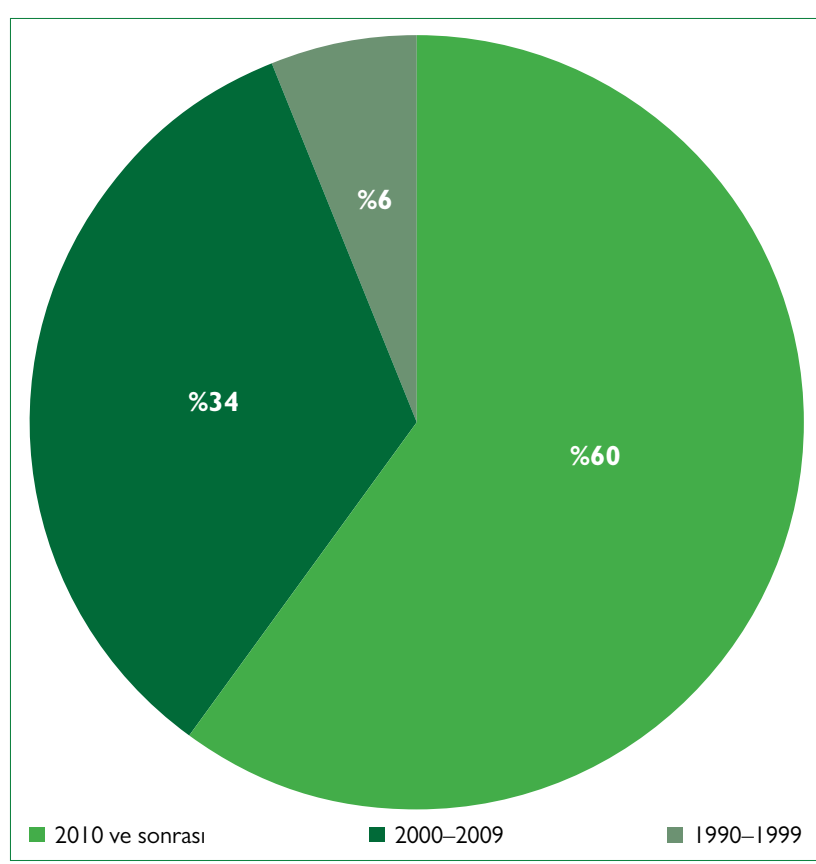

Şekil 7. Gayrimenkul değerleme işi yapan büroların kuruluş yıllarına göre dağıımı (BAP anket verileri-20।8).

BAP: Bilimsel Araştırma Projesi.

özel ya da tüzel şirket, vakıf, STK vb kuruluşların rant arayışı içine girmesi planlama sektörü üzerinde sermaye ve siyasetin baskısını artırırken, hem planlama piyasasındaki iş çeşitlenmiş hem de iş kapasitesi artmıştır. Mekansal planlamanın rant arayışındaki aktörlerce araçsallaştırıldığı bu süreçte, planlama sis-

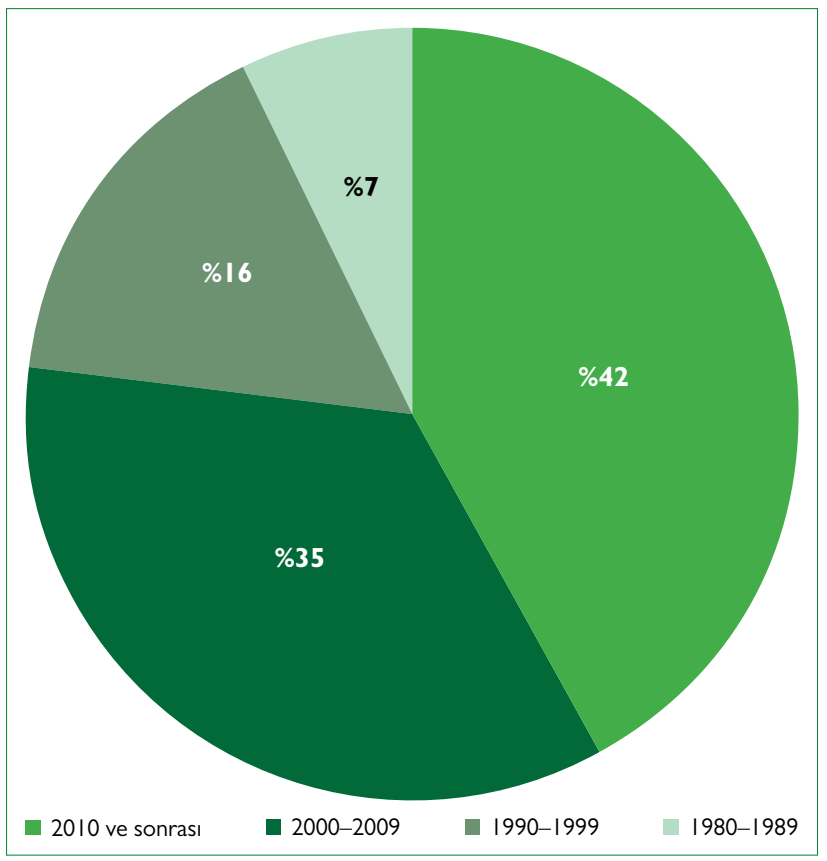

Şekil 8. Şirketlere danışmanlık işi yapan büroların kuruluş yıllarına göre dağıımı (BAP anket verileri-20।8).

BAP: Bilimsel Araştırma Projesi.

temi çeşitli yasal ve yönetsel düzenlemelerle dağınıklaştırılıp, düzensizleştirilmiştir. Rant paylaşımının şiddetlendiği ekonomi politik ortamda, ekonomik ve siyasal baskılara açık olan sektör diğer taraftan 2000 sonrası yeni kurulan planlama okulları ile birlikte plancıların sayısında artış, kamuda daralan istihdam politikaları nedeni ile yeni mezunların serbest planlama piyasasına yönelmesi, dolayısıyla planlama bürolarının sayısının artması ile karşı karşıya kalmıştır.

Serbest planlama bürolarının sektörel ve mekansal analizine odaklanılan bu çalışmada dört önemli bulguya ulaşılmıştır. Birincisi, 2000'e kadar Ankara'da yoğunlaşan planlama büroları 2000 sonrasında hemen hemen tüm Türkiye coğrafyasına yayılmıştır. Ancak planlama bürolarının dağılımı planlama bürolarının sayısı ve etki alanı bakımında coğrafı olarak eşitsizdir. Planlamanın merkeziyetçi yapısı, planlamaya ilişkin kurumların başkentte yer alması nedenleri ile planlama büroları daha baştan itibaren Ankara'da yoğunlaşmıştır. Planlamada 1980 sonrası yerel yönetimlerin yetkilerinin artırılmasına yönelik düzenlemelere rağmen, planlama yetkilerinin parçalı olarak yeniden merkeze dönmesi Ankara'nın bürolar için cazibesini korumasına neden olmuştur. Diğer taraftan neoliberalleşme politikaları ile gayrimenkulün yatırım aracı haline gelmesi, enformel konut alanlarının aflarla yasallaştırılması, kıyı kentlerinde turizm teşvikleri ile her türlü turizm yatırımının ve ikinci konut sahipliliğinin özendirilmesi, yerel yönetimlerin kentlerini modernleştirmek yada güzelleştirmek adına talep ettikleri kentsel tasarım projeleri vb. kentlerde inşaat faaliyetlerinin yaygınlaşmasına yol açmıştır. İnşaat faaliyetlerindeki artışa ve 
yaygınlaşmaya paralel olarak planlama büroları bir taraftan sayıca artmış, diğer taraftan Anadolu kentlerine yayılmıştır.

İkinci bulgu ise planlama bürolarının sayıca artması ve Anadolu'ya yayılmış olmalarına rağmen $A$ grubu özellikle de Ankara merkezli olan planlama bürolarının piyasadan aldıkları payın büyük olmasıdır (Ayrıca bakınız Yoloğlu, 20।4). Diğer taraftan özellikle 1990'larda kurulmuş ve Anadolu'nun ekonomik anlamda gelişmiş kentlerinde yerleşmiş bulunan planlama büroları da kendi bölgelerinde piyasaya hakim olmaktadır. Yeni kurulan büroların iş hacimleri ve etkili oldukları coğrafya ise sınırlı kalmıştır. Bürolar arasında iş alımında eşitsizlik yaratan en önemli faktörlerin başında 1980 öncesi planlamanın kurumsallaştığı dönemde piyasayı düzenleme amaçlı oluşturulmuş karne sistemi gelmektedir. Karne sistemi serbest planlama büroları arasında ve serbest piyasada çaIışan plancılar ile kamuda çalışan plancılar arasında önemli bir kategorik ayrıma yol açmaktadır. Karne sistemi, bürolara yukarıya doğru çıktıkça alt karne gruplarının iş tanımına giren işleri de içerecek biçimde geniş bir alanda iş yapabilme imkanı sunmakta, alt karne gruplarının iş piyasasını ise çok sınırlı tanımlamaktadır. Her tür işi yapabilme yetkisi ile donatılmış A grubu karne sahibi bürolar piyasada tanınırlık, güvenilirlik ve mevzuata hakim olma gibi özelliklerini de kullanarak piyasada hakimiyetlerini kurmuşlardır. Dolayısıyla özellikle 2000 sonrası piyasaya giren planlama büroları haksız rekabet koşulları ile karşılaşmakta, piyasada tutunabilmek adına ya düşük bedellerle iş yapmaya razı olmakta, ya plan değişiklikleri/mevzi plan yapımı, gayrimenkul danışmanlığı gibi işler ile hayatta kalmaya çalışmakta ya da büyük planlama ofislerinin taşeronu olarak çalışmaktadır. Taşeron usulü çalışma bu döneme özgü olmamakla beraber, piyasanın büyümesine paralel olarak yaygınlaşmıştır. Taşeron usulü çalışan büronun karne yükseltmede yaptıkları işleri kullanamaması sistemin yarattığı eşitsizlikleri derinleştirmektedir. Diğer eşitsizlik ise karne yönetmeliğinin kamuda çalışanların karnelerinin yıl bazında yükselmesini, özel sektör çalışanların ise belli sayıda iş bitirme sayısına paralel olarak karne yükseltmelerini öngörmesinden kaynaklıdır. Bazı bürolar karne engelini aşmak ya da karnenin avantajlarından yararlanmak adına kamudan emekli bazı plancıların karnelerini kullanabilmekte bu durum iş alma sürecinde bürolar arasında eşitsizlik yaratabildiği gibi, karnesini kullandıran plancının imzaladığı plandan habersiz olması meslek çevrelerinde rahatsızlık yaratmaktadır.

Üçüncü olarak ise planlama piyasasında planlama işinin özellikle 2000 sonrasında ciddi dönüşüme girmesidir. 2000'li yıllarda mekansal planlamanın temel konusu plan değişiklikleri olmuştur. Plan değişiklikleri planlamanın esnekleşmesine yönelik en önemli düzenlemelerden birisidir. Her karne grubundan büro bu işi yapmakta ancak $F$ grubu bürolar geçimini çoğunlukla plan değişiklikleri işlerinden sağlamaktadır. Hem kamu hem de özel sektörün yoğun olarak talep ettiği plan değişiklikleri çoğu za- man rant beklentisi ile gündeme gelmekte, kentlerin bütüncül planlarını bozmaktadır. Noktasal plan değişiklikleri ile sorunlu hale gelen planlar ise yerel yönetimleri yeni plan yapmaya yöneltmekte, ancak burada da yeni bütünlüklü nazım planlar yerine sıkça revizyon planlar gündeme gelmektedir. Derinlemesine analizlere dayanmayan revizyon planları, parçacıl planlama yaklaşımı ve bu yaklaşımı yaygınlaştırmak adına birbirine entegre olmayan çok sayıda kurum ve kuruluşun planlama yapma ve onama yetkisi Türkiye planlama pratiğini geri götürmüştür.

Diğer taraftan 2000'li yıllarla birlikte şehircilik hizmetleri arasında kentsel dönüşüm, gayrimenkul değerleme, gayrimenkul geliştirme ve şirketlere danışmanlık işleri önemli bir yer bulmaya başlamıştır. Bu durum piyasanın artık yalnızca plan yapmakla dönmediğini, farklı perspektiflerle çalışmanın önemli hale geldiğini gösterir. Bu anlamda $\mathrm{F}$ grubu planlama bürolarının, büyük ölçekli plan alamadıkları için bu yeni ortaya çıkan işlerde çok yoğun şekilde çalışmaktadırlar.

Dördüncü önemli bulgu ise serbest çalışan büroların işveren profilindeki dönüşümdür. Özel sektör en büyük işveren olarak ortaya çıkmıştır. İkinci en büyük işveren ise yerel yönetimlerdir. Özel sektörün daha çok rant odaklı plan değişiklikleri şeklindeki taleplerini düzenleyen serbest planlama büroları için daha da vahim olanı bu tür plan değişikliklerinin 2000 sonrasında kamu kurum ve kuruluşlarından da gelmesidir. Varlığını sürdürebilmesi için kar elde etmek zorunda olan büroların en çok yoğunlaştıkları işlerin plan değişiklikleri olması ve plan değişikliği taleplerinin yoğun olarak rant odaklı olması planlama pratiğinin bugünkü gerçeklerini göstermesi açısından önemlidir.

Türkiye'de mekânsal planlamanın konusu olan birçok plan kamu kurumlarının teknik ve finansal yetersizliğinden dolayı serbest çalışan plancılar tarafından yapılmaktadır. Üstelik planlama artık yalnızca imar planlarından ibaret olmamakta, gayrimenkulden kentsel dönüşüme ve plan tadilatlarına kadar pek çok iş kaleminin piyasada önemli yer tuttuğu gözlemlenmektedir. Emlak eksenli büyüme modeli, istihdam olanakları düşünülmeden açılan yeni planlama okullarından mezun plancılar ile birlikte artan büro sayısı ve karne sistemi bürolar arasındaki eşitsizlikleri derinleştirmektedir. Daralan piyasada haksız rekabet koşulları, dağınık ve düzensiz planlama sistemi ve rant odaklı parçacıl plan talepleri ise serbest çalışan plancıların en önemli sorun alanlarıdır. Planlamanın bir kamu görevi olduğu perspektifi yerini, planlamanın özel şirketler eliyle yapılan "kazanç elde edilen bir iş” olduğu anlayışına bırakmıştır. Neoliberal kent politikaları ile uyumlu kaotik planlama sistemi serbest çalışan plancıları meslek ilkelerine aykırı çıkar gruplarının talepleri ile arasında kalmasına neden olmaktadır. Türkiye planlama sistemi içinde serbest çalışan plancıların çalışma alanlarının ve koşullarının yeniden tanımlanması ve karne sisteminin yeniden düzenlenmesi gerekliliği ortaya çıkmaktadır. 


\section{Teşekkür}

Bu makale Mimar Sinan Güzel Sanatlar Üniversitesi Bilimsel Araştırma Projeleri Birimi tarafından desteklenen 2018-36 numaralı "Türkiye'de Kent Planlama Süreci ve Uygulamanın Kuramla İlişkisi: İstanbul ve Ankara Örnekleri” isimli proje kapsamında kaleme alınmıştır. Mimar Sinan Güzel Sanatlar Üniversitesi Bilimsel Araştırma Projeleri Birimine teşekkürlerimizi sunarız. 


\section{KAYNAKLAR}

Allmendinger, P. \& Haughton, G. (2013). The Evolution and Trajectories of English Spatial Governance: 'Neoliberal' Episodes in Planning. Planning Practice \& Research, 28(1), 6-26.

Atik, S. (2008). Mesleki Deneyim: Farklı Planlama Ölçeklerinde Plancı Olmak. Planlama Meslek Alanı Geçmișten Geleceğe 7-9 Kasım 2007. 8 Kasım Dünya Şehircilik Günü 31. Kolokyum.

Baker, D. C., Sipe, N. G., \& Gleeson, B. J. (2006). Performance-based planning: Perspectives from the United States, Australia, and New Zealand. Journal of Planning Education and Research, 25(4), 396-409.

Balaban, O. (2019). Krizden Kaçış, Krize Kaçış: Türkiyénin Derinleșen Çevre Krizi. Mimarlık Dergisi. say1 409.syf 29-32.

Bektöre, S. (2008). Mesleki Deneyim: Farklı Planlama Ölçeklerinde Plancı Olmak. Planlama Meslek Alanı Geçmișten Geleceğe 7-9 Kasım 2007. 8 Kasım Dünya Şehircilik Günü 31. Kolokyum.

Bilsel, C. (2010). Türkiyéde Şehircilik Çalışmalarının İlk Otuz Yllı. (19271957): Cumhuriyet' in Kent İnşasında Uluslararası Deneyim". Planlama Dergisi. Say1 50. s. 29-46

Boratav, K. Türel, O. and Yeldan, E. (1996). Dilemmas of Structural Adustment and Environment Policies Under Instability: Post 1980 Turkey. World Development. 24 92.syf. 373-393.

Brenner,N. \& Theodore, N. (2002) Cities and the Geographies of "Actually Existing Neoliberalism", Antipode, 34 (3), syf. 349-379.

Duyguluer, F. (2006). İmar Mevzuatının Kayıpları. Planlama Dergisi. sayı 4.syf. 27-37.

Ersoy, M. (2010). İmar Planı Değişiklikleri ve Yargı Denetimi (Mekân Planlama ve Yarg1 Denetimi. 2000). http://www.melihersoy.com/makaleler/ erișim 2.7.2020.

Ersoy, M. (2011). "Yerelden Ulusala Merkezileșerek Aynılaşan Planlama Anlayışı”. Merkezi Yönetim Yerel Yönetim İlişkileri: Özerklik. Türk Belediyeler Birliği. 5.Ulusal Yerel Yönetimler Sempozyumu. Syf. 213-229. Ankara.2013.

Gezim, G \& Kiper, P. (2016). Türkiyénin Seksen Ylllık Kent Planlama Serüveninde Son Otuz Y1lın Değerlendirmesi - İller Bankası Deneyimleri. A. Uğurlar vd. 80 Sonrası Mekân ve Planlama. syf 3-20. Gazi üniversitesi. Ankara.

Gleeson, B., \& Low, N. (2000). Revaluing planning: Rolling back neo-liberalism in Australia. Progress in Planning, 53(2), 83-164.

Grijzen, J. (2010). Outsourcing planning: What do consultants do in a regional spatial planning in the Netherlands. Amsterdam, The Netherlands: Amsterdam University Press.

Hall, T., \& Hubbard, P. (1996). The entrepreneurial city: New urban politics, new urban geographies? Progress in Human Geography, 20(2), 153-174.

Harvey, D. (2001), "Globalization and the Spatial Fix", Geographische Revue, 2 (3): 23-31.

Kahraman, T. (2010). İmar uygulamalarında gizli yolsuzluk: Ayrıcalıklı Özelleştirmeler ve kentsel rant. İş Ahlakı Dergisi, 6, 61-80.

Kentges Belediyeler Anketi Raporu (2016). https://kentges.csb.gov.tr/2016yili-kentges-belediyeler-anketi-haber-229231.erişim 2.7.2020.

Kentleşme Şurası (2009). Mekansal Planlama Sistemi ve Kurumsal Yapılanma. T.C. Bayındırlık ve İskan Bakanlığı. Ankara.

Kıral, Ö. (2010). Şehir Planlama Yarışmaları ve Genç Şehir Plancılar1:1928-1973. Planlama Dergisi. Say1 50.syf 125-139.

Kubin, G. (1994). Kent Plancısı kent Planlama Sürecinde Misafir Sanatçı Değildir. Planlama Dergisi. Sayı 11.syf. 30-34.

Mc Cann, E. J. (2001). Collaborative visioning or urban planning as therapy? The politics of public-private policy making. The Professional Geographer, 53(2), (207-218).

Momani, B. \& Khirfan, L. (2013). “Explaining the Use of Planning Consultants in Ontario Cities" Canadian Public Administration 56 (3): 391-413.
Özler, Ö. A. (2019). Neoliberal Politikaların Kentsel Planlamaya Etkisi: Ankara Çeper Alanı Üzerinden Bir Değerlendirme. Mimarlık Dergisi. Say1 408.

Parker, G., Street, E., Raco, M., Freire-Trigo, S. (2014). In planning we trust? Public interest and private delivery in a co-managed planning system. Town\&Country Planning, 83 (12), 537-540.

Sager,T. (2011). Neo-liberal urban planning policies: A literature survey 1990-2010, Progress in Planning, 6 (4), syf.147-199.

Sarı, V.İ., Yener, I.N. \& İnan,Ö. (2018) Mekansal Planlama Sistemine İlişkin Değerlendirme Raporu, T.C. Kalkınma Bakanlığı Yayın No:2988.

Sönmez, R. (2008) Mesleki Deneyim: Farklı Planlama Ölçeklerinde Plancı Olmak. Planlama Meslek Alanı Geçmişten Geleceğe 7-9 Kasım 2007. 8 Kasım Dünya Sehircilik Günü 31. Kolokyum.

ŞPO 29. Dönem Çalışma Raporu Ankara. (2016-2018). http://www. spo.org.tr/resimler/ekler/2b68761ee5e6253_ek.pdf?tipi=86\&turu= $\mathrm{X} \&$ sube $=0$. erişim 4.7.2020.

ŞPO 28. Dönem Çalışma Raporu. Ankara. (2014-2016). http://www. spo.org.tr/resimler/ekler/31dd73a54d2bc38_ek.pdf?tipi $=868$ turu $=$ $\mathrm{X} \&$ sube $=0$. erişim 5.7.2020.

Şahin, S.Z. (2019). The urbanization policy of Turkey: an uneasy symbiosis of unimplemented policy with centralized pragmatic interventions. Turkish Studies. 20:4. 599-618.

Şahin, S.Z. (2017). Türkiyéde Kamu Yönetimi Temel Kanunu Tasarısından Bugüne Mekânsal Planlama Mevzuatı ve Uygulamalarının Dönüşümü ve Etkileri, Memleket Siyaset Yönetim (MSY), 12 ( 28), syf. 53-80.

Taşan Kok, T. (2016). Interface "Float like a butterfly, sting like a bee"*: giving voice to planning practitioners, Planning Theory \& Practice,17 (4),syf. 621-651.

Taşan Kok, T. (2012). Introduction: Contradictions of Neoliberal Urban Planning, Editörler. Tuna Taşan Kok, Guy Beaten, Contradictions of Neoliberal Planning, Springer.

Taşar, E. (2018). İmar Planı Sürecinde Yerel Halk Katılımı ve İlan-Askı-İtiraz Aşamasının Planlar Üzerindeki Etkisi. İller Bankası Anonim Şirketi Uzmanlık Tezi. Ankara.

Tekeli, İ. (1987). ODTÜ’de Şehir ve Bölge Planlama Eğitimi. Prof. Dr. Ruşen Keleş. Türkiyéde Kent Bilimi içinde syf 65-90.

Tekeli, İ. (2011). Türkiyénin Kent Planlama ve Kent Araștırmaları Tarihi Yazıları. Tarih Vakf, Yurt Yayınları. İstanbul.

Uyar, N. (2008). Mesleki Deneyim: Farklı Planlama Ölçeklerinde Plancı Olmak. Planlama Meslek Alanı Geçmişten Geleceğe 7-9 Kasım 2007. 8 Kasım Dünya Sehircilik Günü 31. Kolokyum.

Waterhout, B., Othengrafen, F., \& Sykes, O. (2013). Neo-liberalization processes and spatial planning in France, Germany, and the Netherlands: An exploration. Planning Practice and Research, 28(1), 141-159.

Yanaşı, E. (2017). İller Bankasının Türkiye Planlama ve Kentleşme Tarihi İçindeki Yeri ve Önemi (1933-1980). İller Bankası Anonim Şirketi Uzmanlık Tezi. Ankara.

Yeşilbağ, M. (2016). Hegemonyanın Harcı: AKP Döneminde İnşaata Dayalı Birikim Rejimi. Ankara Üniversitesi SBF Dergisi, 71 (2), syf. 599-626.

Yoloğlu, A. C. (2019). Planlama Piyasasının İki Yeni Dinamiği: Parçalama ve Tekelleşme İdealkent. Sayı 13.syf 128-151.

Yoloğlu, C. (2008). TMMOB Şehir Plancıları Odasına Kayıtlı Üye Profili. Mesleki Deneyim. 8 Kasım Dünya Şehircilik Günü 31. Kolokyumu. 'Planlama Meslek Alanı; Geçmişten Geleceğe.syf 25-51. Ankara.

Zanotto, J.M. (2019). Detachment in Planning Practice. Planning Theory \& Practice, 20(1), 37-52.

Zorlu, F. (2008). Planlama Meslek Alanında Kuramsal. Pratik ve Yasal Düzlemlerde Çakışma ve Ayrışmalar. Mesleki Deneyim. 8 Kasım Dünya Şehircilik Günü 31. Kolokyumu. 'Planlama Meslek Alanı; Geçmişten Geleceğe.syf 197-214. Ankara. 


\section{EK I. Görüşme Yapılan Serbest Planlama Büroları}

1. Büro A: 1963 yılında kurmuştur. İstanbul. A GRUBU KARNE.

2. Büro B: 1973 yılında kurulmuştur. Ankara. A GRUBU KARNE.

3. Büro C: 1988 yılında kurulmuştur. İstanbul A GRUBU KARNE.

4. Büro D: 1988 yılında kurulmuştur. İstanbul. E GRUBU KARNE.

5. Büro E: 1989 yılında kurulmuştur. Ankara. A GRUBU KARNE.

6. Büro F: 1990 yılında kurulmuştur. Ankara. C GRUBU KARNE.

7. Büro G: 1993 yllında kurulmuştur. İstanbul. A GRUBU KARNE.

8. Büro H: 1993 yllında kurulmuştur. Ankara. B GRUBU KARNE.

9. Büro I: 1994 yllında kurulmuştur. İstanbul. A GRUBU KARNE.

10. Büro J: 1994 yılında kurulmuştur. İstanbul. B GRUBU KARNE.

11. Büro K: 1997 yllında kurulmuştur. İstanbul D GRUBU KARNE.

12. Büro L: 1997 yllında kurulmuştur. İstanbul E GRUBU KARNE.

13. Büro M: 1998'de kurulmuştur. İstanbul. C GRUBU KARNE.

14. Büro N: 2005 yllında kurulmuştur. İstanbul. A GRUBU KARNE.

15. Büro O: 2006 yılında kurulmuştur. Ankara. F GRUBU KARNE.

16. Büro P: 2011 y1lında kurulmuştur. İstanbul. F GRUBU KARNE.

17. Büro R: 2011 yllında kurulmuştur. İstanbul. F GRUBU KARNE 